\title{
economics-of-security.eu
}

Eric van Um

\section{Discussing Concepts of Terrorist Rationality: Implications for Counter- Terrorism Policy}

December 2009

Economics of Security Working Paper 22

European Security Economics

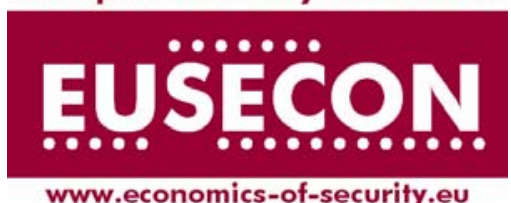




\section{Economics of Security Working Paper Series}

Correct citation: van Um, E. (2009). "Discussing Concepts of Terrorist Rationality:

Implications for Counter-Terrorism Policy". Economics of Security Working Paper 22, Berlin:

Economics of Security.

First published in 2009

(c) Eric van Um 2009

ISSN: $1868-0488$

For further information, please contact:

Economics of Security, c/o Department of International Economics, German Institute for Economic Research (DIW Berlin), Mohrenstr. 58, 10117 Berlin, Germany.

Tel: +49 (0)30 $89789-277$

Email: eusecon@diw.de

Website: www.economics-of-security.eu 


\title{
Discussing Concepts of Terrorist Rationality:
}

\author{
Implications for Counter-Terrorism Policy
}

by

Eric van Um

Institute for Peace Research and Security Policy at the University of Hamburg (IFSH)

Beim Schlump 83

D-20144 Hamburg

vanum@ifsh.de

October 2009 


\section{Table of contents}

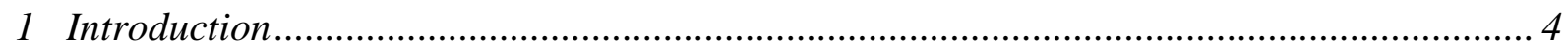

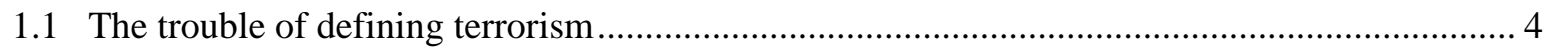

1.2 Challenging the political motive and the rationality of terrorists.............................................. 5

1.3 Research aims, research question and method of analysis................................................ 6

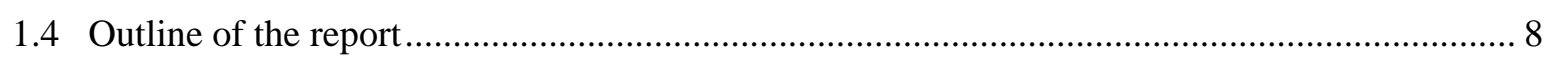

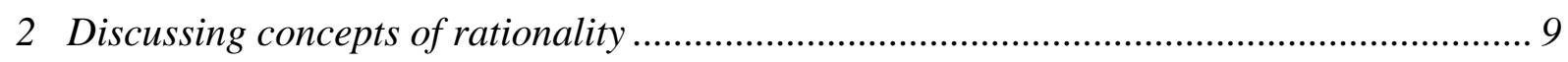

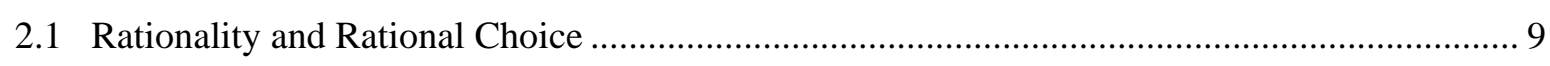

2.2 Criticizing the concept of instrumental rationality and discussing alternatives....................... 11

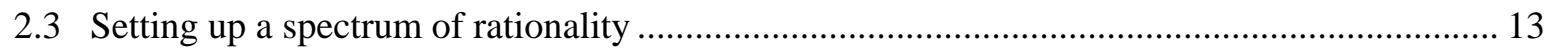

3 Searching for the motives and rationality of terrorists .................................................... 15

3.1 Questioning the instrumental rationality of terrorists .............................................................. 15

3.2 Questioning the political motive of terrorists........................................................................ 16

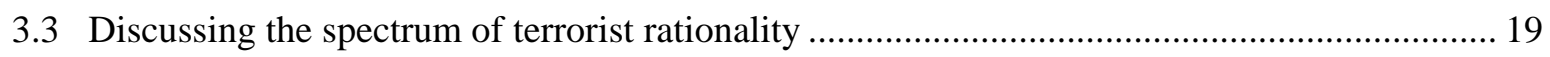

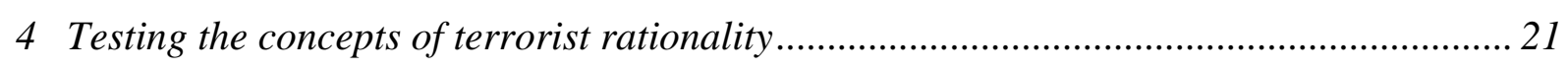

4.1 Deriving assumptions from the axioms of Rational Choice Theory ….................................... 21

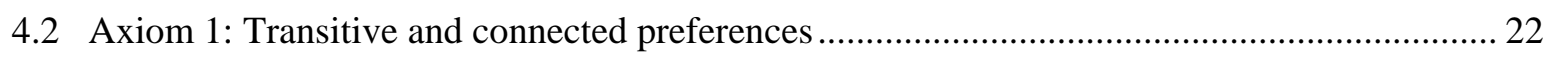

4.3 Axiom 2: Complete information and cost-benefit calculation ................................................. 24

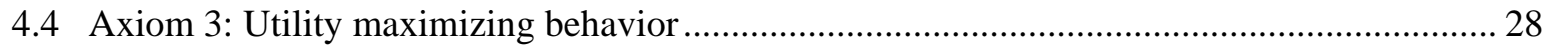

4.5 Axiom 4: The concept of methodological individualism........................................................ 33

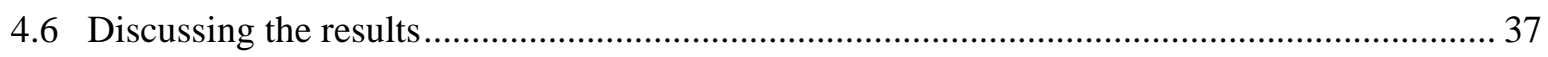

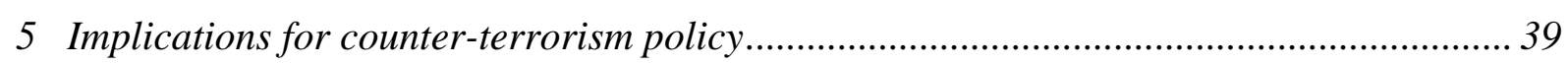

5.1 Emphasizing the need for a spectrum of counter-terrorism measures ..................................... 39

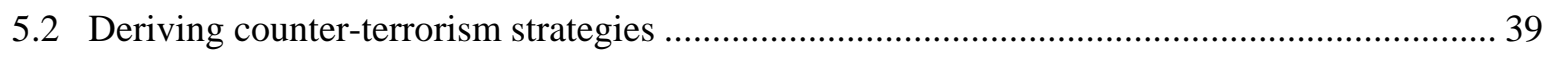

5.3 Discussing the identified counter-terrorism strategies ........................................................... 46

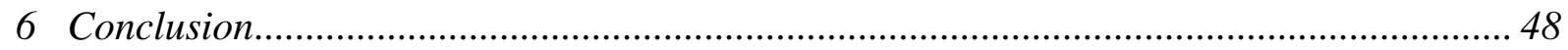

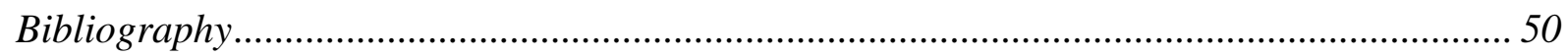




\section{List of Figures}

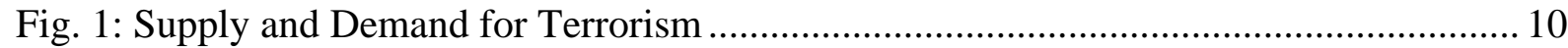

Fig. 2: Increasing the Costs of Terrorism (Income Effect) .................................................. 40

Fig. 3: Reducing the Benefits of Terrorism (Income Effect) ................................................ 41

Fig. 4: Increasing the Costs of Terrorism (Substitution Effect) ............................................. 42

Fig. 5: Reducing the Benefits of Terrorism for Irrational Terrorists (Income Effect) ............. 45

\section{List of Tables}

Table 1: Validity of Basic Axioms of RCT for Concepts of Rationality............................... 14

Table 2: Concepts of Rationality: Objectives and Expected Means Chosen ........................... 19

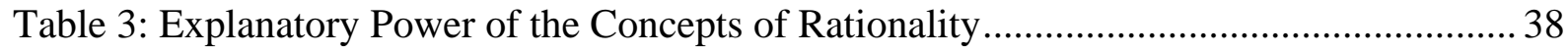

Table 4: Types of Terrorism and Derived Counter-Terrorism Measures ................................ 46 


\section{Introduction}

\subsection{The trouble of defining terrorism}

Scholars of terrorism studies have long struggled to agree on a common understanding of what terrorism is. To date, they have agreed on little more than the fact that terrorism is difficult to define. As a consequence, more than 100, if not more than 200 modern definitions of terrorism have been formulated (see Meisels, 2006: 466). Within those definitions, different aspects of terrorism are stressed including the underlying motivations, applied tactics and chosen targets (Boylan, 2009: 2).

While no consensus has been found on how to define terrorism or terrorists, a meta-study by Schmid and Jongman (1988) provides fruitful insight into the most relevant aspects of definitions of terrorism which have proven valid to the present day. The two researchers analyzed various academic and official definitions of terrorism and identified three main elements as being vital to define terrorism;

(1) the use (or threat) of violence ${ }^{1}$, (2) political objectives and (3) the intention of sowing fear in a target population as a means of achieving these political objectives (Merari, 1993: 215). While definitions of terrorism may vary, "violence and political motives are always key ingredients” (Enders and Sandler, 2005: 260 et seq.). The three identified elements can be found in a high number of definitions of terrorism ${ }^{2}$ and have also become part of the widely influential definition of the US Department of State, which says that "terrorism is defined as politically motivated violence perpetrated against non-combatant targets by subnational groups or clandestine agents, usually intended to influence an audience” (cited in: Ruby, 2002a: 10 and Shugart, 2006: 9).

The notion of political motives or motivations actually allows for a broad range of ideologies and objectives to be included. It can easily be applied to a variety of terrorist groups including left-wing, right-wing, nationalist/separatist, and religious ${ }^{3}$ (Josiger, 2006: 4; Ganor, 2008: 271 et seq.). At the same time, alternative motivations such as economic ones are clearly excluded. Economically motivated violence would be merely considered common criminality (Richardson, 2006: 20). With a focus on political motives of terrorists' behavior, counterterrorism measures have been largely developed in the same context. Yet, as this focus on

\footnotetext{
${ }^{1}$ Violence, however, is rarely seen as an end in itself. Rather, violent means are adopted to accomplish a specific goal (Crenshaw, 2001: 406; Richardson, 2006: 21).

${ }^{2}$ See for instance Crenshaw, 1981: 1; Enders and Sandler, 2004a: 302; Josiger, 2006: 3; Richardson, 2006 : 20 et seqq.

${ }^{3}$ For an elaboration on these specific types of terrorist ideologies, see Josiger, 2006: 4 et seq.
} 
political motives may leave out important aspects, so may derived counter-terrorism policies as a result.

Besides the concentration upon political motives, scholars of terrorism studies have often come to characterize the behavior of terrorists as rational (see Chapter 3). It "is the conventional wisdom among terrorism scholars that [...] terrorists are rational. In fact, this is a long-held view of terrorism scholars” (Miller, 2009: 1). Many scholars, however, hardly reflect on what they perceive as rational action. Without further elaborating on the different concepts of rationality and without defining what rationality really is, one will not make any progress in explaining whether or not terrorists are in fact rational.

According to the instrumental version of rationality, which is often underlying scholarly publications, terrorists are expected to weigh costs and benefits of the available options and to choose the one that promises the highest expected utility in political terms. The characteristics and details of this concept will be further elaborated on in Chapter 2. For further use in this work, terrorism based on instrumentally rational action and linked to political objectives is referred to as instrumentally rational and politically motivated terrorism or politically rational terrorism.

\subsection{Challenging the political motive and the rationality of terrorists}

The concept of instrumentally rational and politically motivated terrorism has increasingly been questioned in the last few years (see for instance Hafez, 2006; Caplan, 2006; Abrahms, 2008; Miller, 2009; Pittel and Rübbelke, 2009). Recent publications have cast heavy doubt on the universal applicability of the concept of politically rational terrorism or even rejected the usefulness of this concept as a whole. What if terrorists in actual fact strive for other objectives than political change? What if terrorists do not always act instrumentally rational? Suicide bombers, for instance, do not seem to opt for the optimal decision when killing themselves.

This thesis can be seen as complementing and structuring the critical work and debate on the universal applicability of concepts of rationality and of the concept of political rationality in particular for the analysis of terrorism.

If terrorists indeed act according to an alternative logic than instrumentally rational calculation or if other objectives than political change are primarily reflected within their agenda, this highly affects counter-terrorism policy. Policies focusing on instrumentally rational and politically motivated terrorism alone would have to be reconsidered. To date, 
however, the effectiveness of counter-terrorism policy has hardly been touched upon within the academic literature. Lum et al. (2006) identify a striking lack of studies concerned about the evaluation of such measures. The authors find that "of the over 20,000 reports regarding terrorism that we located, only about $1.5 \%$ of this massive literature even remotely discussed the idea that an evaluation had been conducted of counter-terrorism strategies” (Lum et al, 2006: 13).

Still, there seems to be evidence both for political motives and instrumentally rational action of terrorists to some degree at least. The challenge for agencies and institutions combating terrorism is then to determine whether or not the behavior and strategies chosen by terrorists reflect such politically rational decision-making.

\subsection{Research aims, research question and method of analysis}

The present work aims to critically determine the explanatory power of concepts of rationality for terrorism with a focus on instrumental rationality incorporating motivations beyond the political one. From the previous discussion one can derive two major questions to guide this study;

Q1: Is the concept of instrumentally rational and politically motivated terrorism capable of explaining all terrorist behavior on empirical grounds?

Q2: Can alternative concepts with varying motives or levels of rationality better explain empirical cases of terrorism?

In the course of this thesis it is shown that the concept of instrumentally rational and politically motivated terrorism in fact is not capable of explaining all terrorist behavior. Counter-terrorism policies which aim at countering politically rational terrorists only may thus be ignoring the true motives of terrorists.

It is further found that none of the alternative concepts, which are discussed in this thesis, account for all terrorist actions. Instead, all of the concepts proved capable of explaining certain aspects of terrorism only. From these results, the following question is derived;

Q3: How should counter-terrorism strategies be designed taking into account the explanatory power of the analyzed concepts of terrorist rationality? 
For the subsequent analysis, counter-terrorism measures are discussed for the various concepts of terrorist motivations and levels of rationality. Developing a spectrum or typology of concepts of terrorist rationality and derive adequate counter-terrorism measures seems to be a promising approach to deal with the various forms of terrorism.

The typology of terrorist motivations and levels of rationality is based on ideal types of concepts and does not allow for a mix of motives for pragmatic reasons. Consequently, this research does not claim to consider all gradual levels of rationality. In reality, terrorists might show a combination of motives and changing rationality over time (Stern, 2003a: 5), which is not reflected within this typology. Still, a typology based on ideal types of terrorist behavior has the advantage of structuring the diverse phenomena of terrorism and allowing for clear counter-terrorism measures to be developed. In this way, differences and similarities of counter-terrorism measures at hand can be identified.

In methodological terms this work is separated into two parts. Part I (Chapter 2, 3 and 4) is on the formulation and testing of assumptions derived from concepts of rationality. This part is thus based on a deductive approach. The identified assumptions serve as criteria to evaluate the explanatory power of various concepts of rationality for terrorist behavior on empirical grounds. Altogether the applied method resembles the approach of a theory or concept test. By contrasting the various concepts of rationality and motivation, an element of comparison is additionally introduced. In total, the method might be described as a comparative concept test. Part II (Chapter 5) derives counter-terrorism measures from the results of Part I, specifying what is to be done to tackle differently motivated and differently rational terrorists. One might regard the approach of Part II as model- or typology-building covering the various concepts of rationality and motivations and derived counter-terrorism measures. A typology of terrorist rationality and of derived counter-terrorism measures allows for classifying the phenomenon of terrorism, analyzing terrorism in a more structured way and giving recommendations on how to combat terrorism.

The study is primarily based on secondary literature and cited empirical case-studies. The number of scholarly publications on terrorism issues has dramatically risen in the last decade so that the major challenge is not finding information but selecting relevant literature out of the mass of publications. Furthermore, the available literature shows two major deficits: Firstly, there is a lack of consensus on basic definitions and of the concept of "rationality" in particular. Rationality is understood in a number of widely differing ways within the literature, complicating efforts to find common ground. Secondly, concepts to determine and 
measure the rationality of terrorists are used in varying ways. The concept of success, for instance, as an important element to determine the level of rationality is not used consistently. As a result, the evaluation of the success of terrorists shows diverging results.

\subsection{Outline of the report}

The thesis is divided into six chapters. The introduction is followed by Chapter 2, which is on concepts of rationality and Rational Choice Theory. The core characteristics of instrumental rationality are elaborated on and contrasted with concepts of bounded rationality and irrationality. Chapter 3 takes a closer look at the importance of rationality within terrorism and challenges the predominant role of the concept of political rationality to explain all terrorist behavior.

The concrete explanatory power both of the concept of instrumental rationality and of alternative concepts is then tested in chapter 4. The aim is to find out whether alternative motives other than political ones and concepts of rationality other than instrumental rationality may better explain terrorist behavior. This chapter thus presents a conceptual framework of terrorist rationality which is the basis for further analysis in the following chapter. The fifth chapter elaborates on the derived counter-terrorism measures for the identified spectrum of prospective terrorist motives and levels of rationality. Moreover, similarities and differences within the framework of identified counter-terrorism measures are further discussed. The results of the study are summarized in the final chapter. In conclusion, recommendations regarding counter-terrorism measures can be made in order to fight various types of terrorism. 


\section{Discussing concepts of rationality}

Before turning to the concrete analysis of terrorist rationality, the notion of rationality and its various concepts need to be discussed and illustrated. This way the concepts can serve as underlying basis for testing rationality in the following chapters. To fully understand the importance of concepts of rationality, criticism on the concepts also needs to be considered and evaluated.

\subsection{Rationality and Rational Choice}

The understanding of rationality in social sciences is nowadays widely based on the behavioral assumptions underlying the neoclassical concept of homo economicus (Simon, 1995: 45; Shugart, 2006: 11). This has been the case at least since the 1950s, when applying economic methods to explain political issues became popular. This approach has become known as Rational Choice Theory (RCT) with the work of authors such as William Riker, Anthony Downs and Mancur Olson (Hindmoor, 2006: 7 et seqq.). To date, Rational Choice has been established as the most influential theoretical model to understand human behavior in social sciences. Still, the concept has also been the object of widespread criticism ${ }^{4}$ and alternatives from other disciplines, such as psychology and sociology, have been proposed (Zimmerling, 1994: 14; Kirchgässner, 2000: 31; Victoroff, 2005: 17).

Rational Choice Theory postulates the individual as subject of analysis that is assumed to possess preferences ${ }^{5}$ and exhibit utility maximizing behavior ${ }^{6}$ (Kirchgässner, 2000: 12). Within the concept, a basic distinction can be drawn between a narrow and a broad version of Rational Choice. The narrow version allows only for action that enhances the personal utility so that individuals act purely selfishly, while a broader version also allows for altruistic goals to be pursued (Diekmann und Voss, 2004: 19; Caplan, 2006: 94). Within the broader version, behavior that benefits not only an individual but also a group the individual feels loyal to may also be considered as rational (Simon, 1995: 48). For most researchers, however, narrow selfishness is considered to be an essential element of rational behavior so that a narrow approach of RCT is often preferred in the academic literature (Caplan, 2006: 94).

\footnotetext{
${ }^{4}$ See Allingham (2006) in particular.

${ }^{5}$ Preferences can be defined as the personal evaluation of options for action with respect to the objectives an individual has set for himself (Kirchgässner, 2000: 14).

${ }^{6}$ To maximize their utility, individuals need to weigh costs and benefits for every available option and choose the one that promises the highest utility defined as benefits minus costs (Parsons, 2005: 10 et seq.; Abrahms, 2008: 79).
} 
A central feature of Rational Choice Theory is the assumption of methodological individualism as a concept to explain collective behavior. In this view, collective behavior is a mere aggregation of individual decisions and the behavior of a group can be explained with recourse to individual behavior (Diekmann und Voss, 2004: 14; Hindmoor, 2006: 1). As a consequence, collective actors such as terrorist groups are said to behave as unitary actors reflecting one stable configuration of preferences and consistent goals (McCormick, 2003: 482).

It was further stated that a rational actor must possess preferences. Rational Choice Theory allows only for preferences, which satisfy the basic conditions of connectivity ${ }^{7}$ and transitivity $^{8}$, so that preferences are stable (McFadden, 1999: 74; Parsons, 2005: 54).

Translating the decisions of instrumentally rational individuals into economic terms and applying these decisions to the issue of terrorism, the cost-benefit-situation is illustrated in Fig. 1.

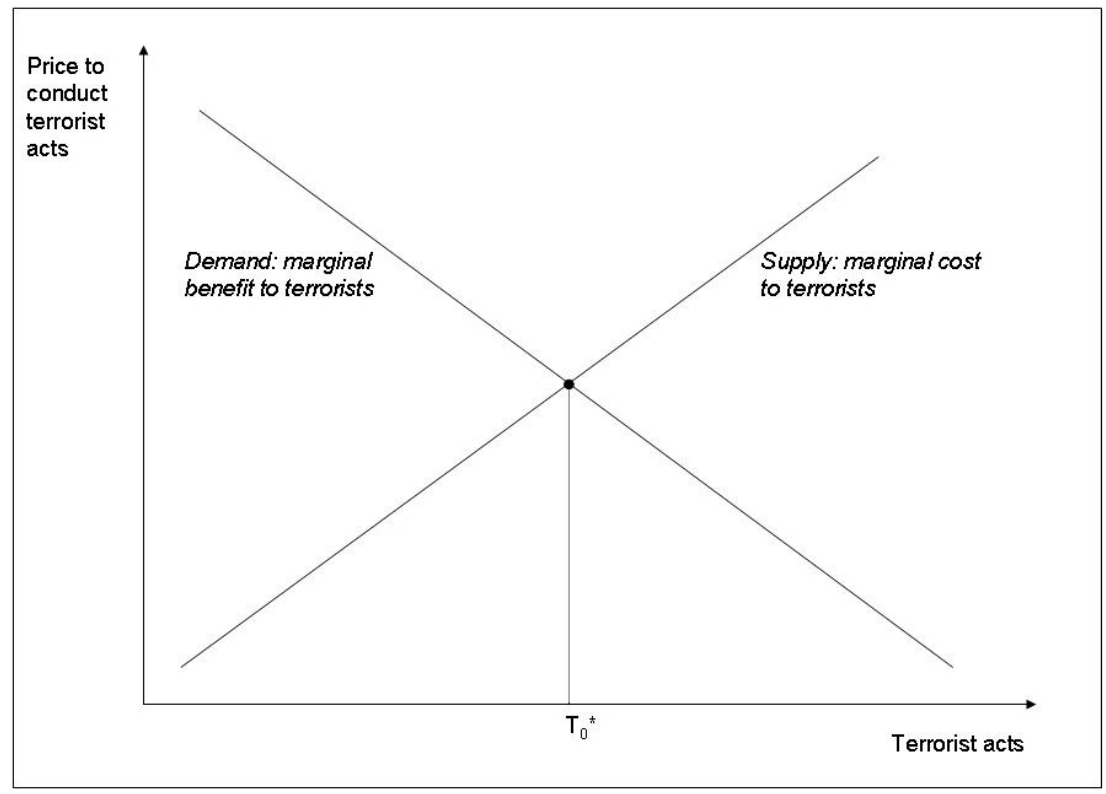

Fig. 1: Supply and Demand for Terrorism

Source: See Frey and Luechinger, 2002a: 3;

Here, terrorists are assumed to maximize utility over time. They will then use violent means as long as the expected benefits outweigh the expected costs (Abrahms, 2008: 79). For the model, however, a differentiation of terrorist acts distinguishing between the numbers of

\footnotetext{
${ }^{7}$ Connectivity means that any two alternatives can be compared in any case (Zagare, 1990: 240).

8 The condition of transitivity demands individuals to compare alternatives and to rank them consistently according to the underlying configuration of preferences. This way, an individual preferring alternative a over $b$ and b over c needs to prefer a over c to have consistent (transitive) preferences (Parsons, 2005: 10).
} 
casualties, for instance, is not included. Any terrorist attack is thus assumed to generate the same benefits and costs for terrorists ceteris paribus.

In actual fact, marginal costs (represented in the supply curve) of terrorist attacks increase for any additional act, so that the curve slopes upwards. The argument for rising costs has traditionally been that additional terrorist acts will only be carried out at higher costs after easier targets have already been hit (Frey and Luechinger, 2002a: 3; Frey and Luechinger, 2007: 226).

Violent acts promise terrorists certain benefits as well, which are reflected graphically within the demand curve. Additional terrorist attacks are assumed to provide terrorists with relatively decreasing benefits, as societies learn to better react to terrorist acts and to decrease the impact of these attacks. The curve, as a result, slopes downwards. The equilibrium of supply and demand curves are reflected by $\mathrm{T}^{*}$ which - according to rational expectations - is the presumed number of terrorists attacks which would occur in a society (Frey and Luechinger, 2002a: 4).

In order to choose the best option available, instrumentally rational individuals must be completely informed about the costs and benefits of all possible options (Sederberg, 1995: 302; Rapoport, 1998: 35). Since such a condition can hardly be satisfied, scholars have come to treat actors as if all information was available and as if individuals made calculations for all options (Simon, 1995: 49).

Important to note, Rational Choice Theory postulates to cover and explain all decisionmaking (Parsons, 2005:6). Even limited empirical evidence refuting the premises of instrumental rationality would thus display a severe limitation of the explanatory power of RCT.

\subsection{Criticizing the concept of instrumental rationality and discussing alternatives}

Perceiving individuals as fully informed, utility maximizing actors has received widespread criticism in the academic debate. "Fully rational man is a mythical hero who knows the solutions of all mathematical problems and can immediately perform all computations, regardless of how difficult they are” (Selten, 1999: 4).

A widely known alternative to instrumental rationality has been presented by Herbert Simon with his concept of bounded rationality. His concept deviates from instrumental rationality in various ways. First, he finds that people are hardly capable of estimating all possible consequences of their actions but will limit their decision on what they perceive to be the 
most crucial aspects of the outcome. Still, consequences might then be misjudged or ignored. Furthermore, even the most rational actor is assumed to take decisions under uncertainty and without the ability to eliminate all possible side effects (Simon, 1995: 46; Weitkunat, 2008: 41 et seq.). Second, bounded rational people, according to the concept, do not consider all options available to them. Instead, the search for alternatives is expected to go on until an option is found, perceived to be adequate and sufficient. The main reason for that lies in the high costs which accrue during the search for additional information (Simon, 1995: 48). Furthermore, additional information may also turn out to be incomplete, erroneous or contradictory (ibid.: 46). The type of information needed might also continually change and thus reduce the value of information that was previously acquired (Parsons, 2005: 15). The described limited process of searching for alternatives and information is termed satisficing by Simon. According to Simon, people do not maximize their utility but rather satisfice to achieve an acceptable level of utility. This view, however, stands in contrast to the utility maximizing concept of instrumental rationality (Selten, 1999: 4; Hindmoor, 2006: 16 et seq.). Bounded rationality needs to be further distinguished from Irrationality. Irrational behavior might be understood both within the context of theories of action and structural theories, which are often described as representing the two main approaches of social sciences to determine individual and collective behavior (Kahl, 2000: 7). Theories of action stress the role of individuals and the deliberate decisions individuals take. Behavioral theories, in contrast, concentrate upon structural influencing patterns which determine the decisions of individuals (ibid.).

For the following analysis, irrationality is seen in the context of Rational Choice Theory as a theory of action only. As bounded rationality is distinguished from instrumental rationality with recourse to the axioms of Rational Choice Theory, so are the same criteria of distinction also applied to define irrationality for further use in this work. Bounded rationality and instrumental rationality thus differ with regards to whether or not they meet specific axioms of Rational Choice Theory.

Irrationality may actually come in many shapes and would not necessarily have to reflect individuals violating all of the axioms of RCT. Still, for the following analysis, irrationality is seen in strict terms and is thus defined by a violation of all of the axioms of Rational Choice Theory (see Table 1).

Criticism of the strict and rigid concept of instrumental rationality has not only been expressed in theory but also on empirical grounds. During the 1970s and 1980s, a number of publications questioned the basic assumptions of Rational Choice Theory (Hindmoor, 2006: 
14 et seq.) and experimental researchers such as Tversky and Kahneman convincingly proved limits of rational behavior. Some of their main findings included:

(1) Individuals have a tendency towards loss-aversion. A secure outcome is preferred over risky outcomes promising the very same expected utility. This violates the principle of utility maximization (Kahneman und Tversky, 2000: 5 et seq.).

(2) Individuals are "poor statisticians". In repeated games, people do not understand the independency of each played game but think of increasing or decreasing chances of success depending on the outcome of previously played games (Gupta, 2008a: 196).

(3) Individuals tend to estimate the probability of outcomes depending on how easy it is to imagine the occurrence of such an outcome. The probability of unlikely events occurring, as a result, is underestimated (Hindmoor, 2006: 16 et seq.). People also hardly calculate costs and benefits regularly but rather adopt bounded rational heuristics to make decisions (McFadden, 1999: 94).

In a recent publication, Akerlof and Shiller (2009) demonstrate that decisions in the economic field are not based on purely rational calculation processes. Instead, so called "animal spirits" such as feelings, impressions, confidence and illusions play a crucial rule in decision-making. Regarding the case of saving for instance, conventional (neoclassical) theories suggest that people will rationally choose how much to save based on their income. In reality, however, it is more likely that individuals will decide how much to save depending on the saving ratio of neighbors and family. The result is often saving too much or saving too little (Akerlof and Shiller, 2009: 119 et seqq.).

There have been a number of further experiments which by and large made clear that people do not act as rationally as postulated by Rational Choice Theory. Their behavior can rather be described in the context of bounded rationality or irrationality (Weibull, 2004: 85; Hindmoor, 2006: 14 et seq.). While many researchers still approach terrorism with recourse to instrumentally rational explanations, there would be good reason to expect terrorist behavior to be imperfect and bounded rational.

\subsection{Setting up a spectrum of rationality}

The various concepts of rationality ranging from instrumental rationality to irrationality and the underlying basic axioms are illustrated in Table 1. 
Table 1: Validity of Basic Axioms of RCT for Concepts of Rationality

\begin{tabular}{|c|c|c|c|c|}
\hline & & $\begin{array}{l}\text { Instrumental } \\
\text { rationality }\end{array}$ & $\begin{array}{l}\text { Concepts of rationality } \\
\text { Bounded rationality }\end{array}$ & Irrationality \\
\hline \multirow{7}{*}{ 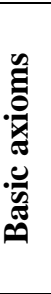 } & Connectivity of preferences & Yes & Yes & No \\
\hline & Transitivity of preferences & Yes & Yes & No \\
\hline & Complete information & Yes (as if) & No & No \\
\hline & Cost-benefit-calculation & Yes (perfect) & Imperfect $^{9}$ & No \\
\hline & Outcome known & Yes (anticipated) & No (uncertainty) & No \\
\hline & Utility maximization & Yes & No, satisfacing & No \\
\hline & Methodological individualism & Yes & Yes & No \\
\hline
\end{tabular}

Important to note, instrumental rationality understood in the previously described sense is based on restrictive assumptions. Scholars have at times suggested loosening the axioms and still to capture such a less restrictive version as instrumental rationality (see Parsons, 2005: 14). As an ideal form of instrumentally rational behavior and as a concept in stark contrast to boundedly rational and irrational behavior, however, sticking to a restrictive version does make sense.

With the identified concepts of rationality in mind, the next chapter will discuss these concepts with regard to terrorism.

\footnotetext{
${ }^{9}$ Compare the use of heuristics as a pragmatic substitute for thorough cost-benefit analysis.
} 


\section{Searching for the motives and rationality of terrorists}

It was stated before that most scholars of terrorism studies, especially, but not limited to the economic field, think of terrorists as instrumentally rational and politically motivated. ${ }^{10}$ Such a view may, however, ignore alternative motivations and levels of rationality of terrorists.

\subsection{Questioning the instrumental rationality of terrorists}

Scholars have at times proposed to consider terrorists as deviating from acting instrumentally rational and consider their actions to be rather bounded rational or even irrational. The assumption of irrational terrorists, in particular, has caused widespread attention in the academic literature (see Ruby, 2002b: 17).

Psychological analyses were formerly thought of as providing an adequate answer to the roots of terrorism based on the idea that terrorists were mentally abnormal or disturbed (ibid.). Empirical research and interviews conducted with former terrorists, however, have widely rejected the idea that terrorists are mentally ill or psychotic or that they feature common mental defects or disorders (Ruby, 2002b: 15 et seq.; McCartan et al. 2008: 60; Post, 2008: 12). Instead, there is good reason to believe that "the outstanding common characteristic of terrorists is their normality" (Crenshaw, 1981: 390) and that "terrorists, by and large, are not insane at all” (Richardson, 2006: 32). These findings suggest terrorists to be rational actors.

Still, it should not be left unmentioned that a great deal of studies which finds terrorists to be mentally normal is based on only a small number of empirical cases. "The study of terrorism still lacks the foundation of extensive primary data based on interviews and life histories of individuals engaged in terrorism. Far too often, psychological hypotheses are based on speculation or are derived from such a small number of cases that the findings cannot be considered reliable” (Crenshaw, 2001: 410).

In contrast to the psychological studies discussed before, recent research indicates an aboveaverage rate of psychological disturbances of terrorists (COT, 2007). Analyzing the personality of five so-called lone-wolf terrorists ${ }^{11}$, evidence is found for three of them suffering from personality disorder such as schizophrenia, anxiety disorder and obsessiveness. For four of them, depression was a considerable problem (ibid.: 86). While this result

\footnotetext{
${ }^{10}$ See for instance Crenshaw, 1981: 380; McCormick, 2003: 481; Shugart, 2006: 11; Enders and Su, 2007: 35, Frey and Luechinger, 2007: 225; Jarvis, 2009: 9.

${ }^{11}$ Lone-wolf terrorists are individually acting terrorists who do not belong to an organized group and act without the influence of a leader or hierarchy (COT, 2007: 6).
} 
certainly does not prove a general tendency of mentally disturbance of terrorists and while the study of only five cases hardly allows for general conclusions, the analysis nevertheless suggests considering the findings of mentally sane terrorists with caution.

Even more important, terrorists' irrationality is often rejected based on clinical studies and understood in a psychological sense ${ }^{12}$. Yet, these conclusions are not derived from a thorough testing of whether or not terrorists meet the premises of Rational Choice Theory. In order to evaluate terrorist rationality from an academic point of view, however, such analysis is essential. Mentally disturbed people can easily be thought of as behaving according to the premises of Rational Choice Theory, while apparently sane people may fail to meet these premises due to (medically sane) calculation errors. It needs to be stressed again that irrationality is thus defined as a violation of the axioms of RCT for the following analysis but not as mental disturbance.

\subsection{Questioning the political motive of terrorists}

As an alternative to challenging the rationality of terrorists, terrorists may also be thought of as being instrumentally rational actors who are motivated by something other than political goals. Economically motivated terrorism reflecting economic objectives represents one of these conceivable alternatives. One of the main difficulties of such analysis lies in the fact that economic goals or motivations can contain different meanings. Such a distinction is hardly made in the academic literature, however: Firstly, economically motivated terrorism can be understood under the premise of terrorists trying to cause economic damage and inflict as many casualties as possible. Terrorism might hence be a means of causing widespread disruption and to inflict economic damage of an adversary. ${ }^{13}$ Such argumentation and behavior can be perfectly in line with political motives. Terrorists would then try to achieve concessions from a targeted government as ultimate goal by causing widespread economic disruption (Libicki, et al. 2007: 11).

For some terrorists, causing economic damage might also constitute an end in itself replacing political goals as ultimate object. One might still call such behavior instrumentally rational and assume that the ultimate goal of terrorists is to damage the targeted economy to the most possible extent. While clinical studies might come to the conclusion that terrorists aiming at destruction as an ultimate objective are mentally disturbed, rationality in an economic sense

\footnotetext{
${ }^{12}$ See for instance Crenshaw, 1981; Ruby, 2002b; Richardson, 2006; Abrahms, 2008; McCartan et al. 2008; Post, 2008.

${ }^{13}$ For an overview compare Jackson et al. (2007).
} 
can nevertheless be given as long as those terrorists behave according to the premises of Rational Choice Theory. In the following, this concept of rationality is referred to as instrumentally rational and economically motivated terrorism or economically rational terrorism.

Secondly, economically motivated terrorism can also be a means to - simply stated - making money. Instead of striving for political objectives, terrorists - no matter what their official statements say - may pursue terrorist means to enrich themselves. Yet, some authors subsume such behavior lacking political demands as crime and reject motivations of personal enrichment as a form of terrorism (Sandler and Enders, 2004b: 1).

In actual fact, terrorism and crime are often thought of as being distinguishable from one another: Firstly, terrorism is originally said to be motivated by ideological motives and political objectives, while criminals are purely interested in economic profit (Shelley et al., 2005: 34; Bovenkerk and Chakra, 2007: 32). Secondly, terrorists aim at political change while criminals try to keep the status quo beneficial to their illegal activities (Sanderson, 2004: 55; Gupta, 2008a: 148). Finally, criminals try to avoid media and public attention, while terrorists desire such attention for the purpose of making their cause known (Hutchinson and O’Malley, 2007: 1100). The offered criteria may lack completeness but nevertheless show that a distinction may be possible. However, distinguishing between terrorism and crime has become more complicated during the last years and is not as easily done as might be expected. Both phenomena have converged with regard to a number of characteristics: Firstly, some terrorist groups and criminal organizations have repeatedly cooperated on a case by case basis or even permanently (Sanderson, 2004: 49; Dishman, 2005: 246; Gupta, 2008a: 149).

Secondly, terrorist groups, to a growing extent, use criminal activities to finance their still ultimately politically-motivated actions. For that purpose, terrorists have, on various occasions, developed in-house capabilities within their organization responsible for criminal activities (Gupta, 2008a: 149). Hezbollah, for instance, has started smuggling methamphetamine and cigarettes (Sanderson, 2004: 51; Shelley et al. 2005: 36). Al-Qaeda cells in Spain and Italy and the Tamil Tigers in Sri Lanka financed their activities through the use of credit card fraud, while al-Qaeda was furthermore active in smuggling commodities such as diamonds (Shelley et al, 2005: 36; Hutchinson and O’Malley, 2007: 1097). The Irish Republican Army (IRA) took on the methods of criminal gangs smuggling livestock and cars (Dishman, 2001: 48).

Thirdly, some terrorist groups have even transformed into criminals or for-profit terrorists (Rosenthal, 2008: 481). Political motives may have become obsolete for these groups but 
making money is what they are aiming at (Shelley et al., 2005: 37). The Colombian group Fuerzas Armadas Revolucionarias de Colombia (FARC) provides a good example. In 2004, FARC spent \$282 million (on weapons and explosives in particular), while the organization raised approximately $\$ 1.36$ billion. “This disparity suggests that the group’s grand strategic objective is making money” (Rosenthal, 2008: 485). In the Philippines, the Islamic terrorist group Abu Sayyaf originally pursued political goals but has more and more transformed into a criminal organization (Shelley et al., 2005: 37).

Criminal groups, on the other hand, have been observed to extend the spectrum of their activities and include political issues as part of their agenda. At times, criminal organizations even transform into terrorist groups trying to accomplish political objectives (Bovenkerk and Chakra, 2007: 32; Oehme, 2008: 82). With terrorists and criminals converging, they turn into hybrid organizations, merging political and economic motives and objectives (Dishman, 2005: 247; Shelley et al., 2005: 6). This convergence makes it more difficult to apply the classical criteria of terrorism and criminality and to distinguish between the apparently separable phenomena. In the following, terrorism approaching criminal activities and following a motive of self-enrichment is referred to as instrumentally rational and selfenriching terrorism or rationally self-enriching terrorism.

As an alternative explanatory concept, it has been suggested that people do not become terrorists for political but for social reasons. Ideology and political objectives might play a less important role than expected but the "desire to belong to a group and gain the material and psychological rewards provided by membership” (Moore, 2005: 9) might be predominant which helps individuals to "become the person they want to be as members of the group, in which they claim membership" (Gupta, 2008b: n. pag., section: The Why of the Megatrends). Similarly, terrorist acts of socially motivated terrorists might not primarily aim at accomplishing political concessions. Instead, they could reflect an intention to develop and intensify social linkages between members of a terrorist group and to keep the group as a social unit alive (Wintrobe: 2003: 2; Moore, 2005: 8; Abrahms, 2008: 96). This concept of terrorist rationality is referred to as instrumentally rational and socially motivated or socially rational in the following. Under the assumption that terrorists indeed are primarily socially motivated, one would expect their actions to aim at maintaining the group's existence and developing strong ties between the individuals but not on the pursuit of a stated political objective. "The survival of the group is no longer a means to an end but an end in itself [...]" (McCormick, 2003: 490). 


\subsection{Discussing the spectrum of terrorist rationality}

To summarize, concepts of rationality may deviate from the concept of instrumentally rational and politically motivated terrorism in two ways: Firstly, instrumental rationality may be limited or even non-existent, making the actions of terrorists bounded rational or even irrational. Secondly, and still under the assumption of instrumental rationally, the primary motivation may not consist of accomplishing a political but some other goal.

The previous discussion allows us to create an appropriate framework or spectrum for the various types of terrorism. At one end of this spectrum, terrorists can be thought of as instrumentally rational actors, with transitive and connected preferences underlying their utility maximizing decisions. This utility may consist of political goals, but can also contain social or economic utility as well. In the middle we find bounded rational terrorists. While decisions may not always represent a utility maximization process for them and may be based on incomplete information, some of the basic assumptions of Rational Choice Theory remain valid. At the other end of the spectrum are irrational actors. They lack the sort of rationality we expect from an instrumentally or bounded rational individual. Irrational actors hardly calculate costs and benefits before making decisions. Most importantly, irrational actors do not meet the basic axioms of preference connectivity and transitivity. Table 2 illustrates this spectrum of rationality and motivations of terrorism as well as objectives and expected means chosen of the various types of terrorists in detail.

Table 2: Concepts of Rationality: Objectives and Expected Means Chosen

\begin{tabular}{|c|c|c|c|}
\hline $\begin{array}{c}\text { Level } \\
\text { of rationality }\end{array}$ & $\begin{array}{l}\text { Concept of terrorist } \\
\text { rationality }\end{array}$ & Objective & Expected means chosen \\
\hline \multirow{4}{*}{ 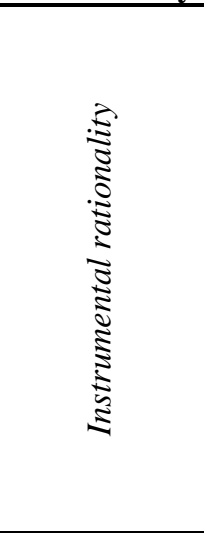 } & Politically motivated & Political change & $\begin{array}{l}\text { Traditional: Selective acts with limited } \\
\text { number of casualties. }{ }^{14} \\
\text { New terrorism }{ }^{15} \text { : Non-discriminating } \\
\text { high-profile acts causing severe damage } \\
\text { and inflicting high number of casualties. }\end{array}$ \\
\hline & Socially motivated & $\begin{array}{l}\text { Intensify bonds with } \\
\text { other members / keep } \\
\text { group alive }\end{array}$ & $\begin{array}{l}\text { Low-profile acts to keep public attention } \\
\text { low and not to endanger group as social } \\
\text { unit. }\end{array}$ \\
\hline & $\begin{array}{l}\text { Motivated by self- } \\
\text { enrichment }\end{array}$ & Self-enrichment & $\begin{array}{l}\text { Low-profile acts promising economic } \\
\text { benefits. Limited number of casualties } \\
\text { resulting to keep public attention low. }\end{array}$ \\
\hline & $\begin{array}{l}\text { Economically } \\
\text { motivated }\end{array}$ & $\begin{array}{l}\text { Economic disruption } \\
\text { and mass casualties }\end{array}$ & $\begin{array}{l}\text { High-profile acts to maximize damage } \\
\text { and number of casualties. }\end{array}$ \\
\hline
\end{tabular}

\footnotetext{
${ }^{14}$ See Hoffman (1999: 8).

${ }^{15}$ Compare Hoffman (1999) for an elaborate view on this phenomenon. New terrorism is understood here as Islamic terrorism often inspired by a Jihadist agenda which has increased in the last decade.
} 


\begin{tabular}{|c|c|c|c|}
\hline 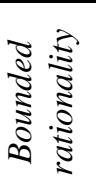 & Unclear & $\begin{array}{l}\text { Unclear; broad range } \\
\text { of goals possible }\end{array}$ & $\begin{array}{l}\text { Unclear, due to unspecified goals. } \\
\text { However, political motivation often } \\
\text { assumed. Selected means may not } \\
\text { represent the optimal ones available. }\end{array}$ \\
\hline : & Unclear & $\begin{array}{l}\text { Unclear; broad range } \\
\text { of goals possible }\end{array}$ & $\begin{array}{l}\text { Unclear, due to unspecified goals. } \\
\text { Moreover, selected means may not } \\
\text { represent the optimal ones available. }\end{array}$ \\
\hline
\end{tabular}

In the following, the explanatory power of the various concepts describing terrorists' behavior

is tested. Only this way can we learn more on how to design adequate counter-terrorism measures. 


\section{Testing the concepts of terrorist rationality}

From the discussion of chapter 2 and 3 on concepts of rationality, assumptions can be derived from Rational Choice Theory, which shall guide as criteria for the following analysis. These assumptions are tested for the previously introduced concepts of terrorist rationality. ${ }^{16}$

\subsection{Deriving assumptions from the axioms of Rational Choice Theory}

According to the concept of instrumentally rational and politically motivated terrorism, terrorists are assumed to (1) have transitive and connected preferences, (2) act as if they have complete information, and are thus in a position to compare the costs and benefits of all options, so that they (3) choose the option, that promises the highest utility in political terms. Important to note, this option does not necessarily have to be based on violent means. (4) Moreover, the degree of rationality is expected to be consistent on the individual and collective level.

Firstly, terrorists are assumed to have transitive (well-ordered) and connected preferences. This basic axiom can be tested by a look at their statements and agenda as well as their concrete actions (section 4.2). For terrorists to meet this demand, one would expect continuity and an unchanged hierarchy of goals and targets between past and present statements and actions. Contradicting evidence would suggest an absence of internal consistency of the preferences of terrorists (Mandel, 1987: 3). Secondly, for the axiom of complete information underlying the cost-benefit calculations of terrorists, terrorists are expected to base their decision with regard to all costs and gains resulting from the different options (Sandler and Enders, 2004b: 19) (section 4.3). Thirdly, choosing violent action as the option promising the highest utility, one should expect terrorism to succeed for some of the time, at least, regarding the formulated political demands (section 4.4). Finally, the concept of methodological individualism demands consistency between the individual and collective levels of terrorism (section 4.5). If, however, rationality and motivations on the level of individuals and the group differ, this would violate the axioms of methodological individualism.

These axioms met, terrorists act in line with the concept of politically rational terrorism. Yet, if one or more of those axioms should be violated on empirical grounds, three main lines of prospective arguments arise:

\footnotetext{
${ }^{16}$ This approach resembles the approach chosen by Abrahms (2008). In contrast to the framework of Abrahms, however, varying degrees of rationality are also tested, which makes it necessary to include alternative assumptions than the ones used in the work of Abrahms.
} 
(1) One might be inclined to assume irrational or boundedly rational behavior of terrorists.

(2) Terrorists might not act in accordance with the assumed objective of political motives. Terrorists might still be instrumentally rational actors but try to pursue other than political goals.

(3) Instrumental rationality might be found on the level of terrorist groups' leaders but not on the level of followers responsible for carrying out the attacks. For that argument to be analyzed one would have to closer examine inter-terrorist group procedures and structures.

\subsection{Axiom 1: Transitive and connected preferences}

The concept of instrumental rationality assumes that individuals possess transitive, stable and connected preferences. Whether this is the case for terrorism is further discussed with two derived assumptions in the following: Firstly, terrorists are expected to be aware of the aspired objective they pursue as a condition to possess transitive preferences. Secondly, the consistency and stability of preferences of terrorists is directly analyzed.

(A) Awareness of the aspired objective ${ }^{17}$ : In order to meet the basic conditions of instrumental rationality, terrorists need to understand and need to have the ability to define what their concrete goal is. Only then can they aim for this goal. Contradicting evidence would suggest that terrorists do not possess a consistent configuration of preferences and thus violate one of the basic principles of instrumental rationality.

For politically stated motives, there is actually evidence that terrorists are not always fully aware of the aspired political objective of their group. While there may be a variety of empirical studies supporting the view that terrorists indeed know what their objectives are, case studies on the IRA and al-Qaeda point in another direction. The results of these studies make clear that terrorists were unaware of the political context and the political goals stated by their respective leaders (Richardson, 2006: 112; Abrahms, 2008: 99). Such limited awareness of the aims of terrorist groups is not confined to followers or sympathizers of terrorist groups. In a publication as of 2006, Richardson shows that the leaders of famous but

\footnotetext{
17 The assumption of terrorists pursuing one ultimate goal, which is underlying this analysis, reflects a limited approach. It is not hard to imagine that terrorists try to accomplish a number of different objectives, which may stem from the political, economic and social spectrum.
} 
inherently different terrorist groups were unable to explain the political objectives and societal changes wanted (Richardson, 2006: 112).

Alternative concepts to explain this limited awareness of the aspired objectives might better account for the empirical findings. Similar to the concept of political rationality, however, the concept of bounded rationality is neither capable of dealing with these findings, since even bounded rationality expects terrorists to know what they want. Irrationality, in contrast, may be referred to to explain those cases when terrorists indeed were unaware of the goals they were striving for, but has a hard time explaining situations when they did know what they wanted. Reconsidering alternative motivations for the concept of instrumental rationality may be a more promising approach to account for all terrorism. For the concepts of rationally selfenriching terrorism, economically rational terrorism and socially rational terrorism, there is no need to be fully aware of the stated political goals of the organization, which stand behind economic or social motives. These concepts may account both for situations where terrorists know what they want in political terms but also for situations when terrorists are not fully aware of the political objective of their group.

(B) Consistency and stability of preferences: The preferences of instrumentally rational terrorists are assumed to be exogenously given and thus stable (Parsons, 2005: 8). Under the assumption that terrorists' preferences are reflected within the official statements and the agenda of the group, one would have good reason to expect a consistent formulation of goals to prove the validity of the concept of politically rational terrorism. A change of objectives or statements over time, however, would violate the condition of transitivity.

In a recent analysis of 2008, Abrahms concludes that such consistency is indeed hardly given within the agenda and statements of terrorist groups (Abrahms, 2008: 87). The author finds evidence for a significant alteration of objectives and statements of organizations such as alQaeda, the Basque group Euskadi Ta Askatasuna (ETA) and the Kurdistan Workers' Party (PKK) during the course of time. Taking ETA as an example, Abrahms finds that "its political goals have wavered from fighting to overturn the Franco dictatorship in Spain to targeting the emergent democratic government” (Abrahms, 2008: 88). The PKK alternated between jihad, nationalist and Marxist ideas (ibid.). In a study by Stern (2003b), she similarly finds that “over its life span, al Qaeda has constantly evolved and shown a surprising willingness to adapt its mission" (Stern, 2003b: Third paragraph, n. pag.). These findings are further supported by a study conducted by Picco (2005). Evaluating the goals of al-Qaeda, Picco 
concludes that "[t]he political objectives of Al Qaeda have been as fleeting as the wind" (Picco, 2005: 75 et seq.).

Still, contrasting findings can also be found which seem to prove a consistent and stable configuration of preferences of some terrorist groups, at least. Research on the IRA, for example, shows that the political objective of the group remained unchanged over time. "There is no question that these groups had used terrorism in order to achieve a political end that [...] remained constant” (Picco, 2005: 72).

To summarize, some terrorist groups may keep their goals even for decades, while other groups have been shown to modify and adapt their objectives. Referring to the latter, this change of goals reflects intransitive preferences and thus violates one of the basic axioms of politically rational terrorism.

Turning to alternative concepts of rationality, the respective explanatory power of these remains also limited. Bounded rationality is based on the same assumptions regarding the configuration of preferences as instrumental rationality. As a consequence, the explanatory power of this concept remains confined to cases where objectives and statements remained stable over time. The concept of irrationality, in contrast, accounts only for cases in which this was not true.

Yet, apparently inconsistent statements with regards to political goals are compatible with a motive of self-enrichment. Keeping a group alive by adapting political statements to ultimately make money is perfectly reasonable and rational. For those terrorists, preferences reflect economic instead of political goals. These may remain constant, even if political statements are subject to change. At the same time, the possibility of stable political statements over time is not excluded. The same line of argument holds true for the concept of economically rational terrorism. Consistent preferences regarding economic objectives do not necessarily have to reflect constant political goals. Finally, socially rational terrorism can also be explained. Terrorists do not have to formulate consistent political goals to keep their organization alive if political statements just represent a false front. If, actually, the major goal of terrorists is to keep their group intact, and if this objective remains stable, then the best option is to adapt their agenda and statements so their group can survive.

\subsection{Axiom 2: Complete information and cost-benefit calculation}

If terrorists indeed act instrumentally rationally one would have reason to believe that they act as if they possess complete information and thoroughly calculate costs and benefits of their 
available options. These axioms are tested with recourse to two derived assumptions: Firstly, the cost-benefit-analysis of terrorists is supposed to be based on complete information. Secondly, rational terrorists are expected to correctly anticipate the outcome of their actions.

(A) Thorough and precise calculation process: The concept of instrumental rationality postulates that terrorist groups only decide to commit violent acts after thoroughly weighing costs and benefits of all (violent and non-violent) alternatives available. Evidence which proves a limited use of such calculations and/or imperfect calculation processes would speak against instrumental rationality but rather favor the validity of irrationality or bounded rationality.

Empirical analyses have shown that terrorists shifted their modes of attack away from kidnappings after US embassies had been fortified. Following this, however, political assassinations increased significantly. Similarly, the installation of metal detectors at U.S. airports lead to a reduction of hijackings of aircrafts by 13 percent per quarter, while other hostage-taking incidents significantly rose by almost 10 percent per quarter (Enders and Sandler, 2002: 14; Shugart, 2006: 13). This phenomenon has been described as the so called substitution effect of terrorism. Accordingly, terrorists have substituted across targets whenever targets that were previously aimed at became more costly to attack. To summarize, the findings indicate that terrorists wisely calculate how to spend scarce resources on activities promising a high outcome in political terms.

There is further evidence of thorough cost-benefit analysis underlying terrorist behavior presented by Enders and Sandler (2002). Under the constraints of limited resources, terrorists are assumed to commit more complex acts such as skyjackings less frequently than others. With the aid of ITERATE ${ }^{18}$ data, the authors indeed find evidence for such behavior pointing towards a thorough calculation process preceding the decision-making of terrorists. Complex attacks had longer cycles than those, which could be easier conducted and hence took place in shorter cycles (Enders and Sandler, 2004b: 6). The previously described examples show that, at times at least, terrorists indeed behave accordingly to instrumental rationality with regard to the calculation process. The results may, however, also be seen in the context of bounded rationality.

On the other side, empirical evidence shows that terrorists calculate only boundedly before deciding which option to choose, at times, speaking against politically or otherwise motivated instrumentally rational terrorism. Emotional factors such as revenge and a desire for fame

\footnotetext{
${ }^{18}$ ITERATE (International Terrorism: Attributes of Terrorist Events) is a data set on International Terrorism (see Enders and Sandler, 2004a: 304).
} 
may prevent a rational and sober-minded calculation process and the precise weighing of costs and benefits (Crenshaw, 1981: 393; Richardson, 2006: 113). Terrorists' actions are rather the result of spontaneous and expressive decisions and less than perfectly calculated processes in this case (Hindmoor, 2006: 14 et seq.). Merari (1993) cites the Moluccan case in the Netherlands and the Armenian case regarding Turkey as examples of expressive terrorism. In the 1970s, the Moluccan community in the Netherlands originally stemming from the former Dutch colony in Indonesia felt neglected by its former colonial power. Blaming the Dutch government for not defending the newly created Moluccan Republic within Indonesia, some Moluccans in the Netherlands began turning to violent means and using terrorist tactics to draw attention to their case. The result was a number of terrorist incidents including the hijacking of a passenger train (Merari, 1993: 236). "The dominant motivation which has driven the young men and women who carried out the acts of violence belonged to the emotional realm rather than to the domain of rational political planning” (ibid.). The terrorists, consequently, were lacking a thorough and precise calculation process underlying their decisions and furthermore did not define demands or goals they tried to accomplish (ibid.).

A similar case cited by Merari refers to Armenian terrorism of the 1970s and 1980s. Armenian terrorist groups at that time conducted violent attacks as an act of revenge for the Turkish massacre of Armenians in 1915. Such behavior again reflects a spontaneous and emotional state of mind rather than being the result of a sober and well-thought out calculation process (ibid.).

To summarize, the cited examples and the inherently expressive moments argue for the validity of irrational behavior. As a consequence, the concept of irrationality may be compatible with the Moluccan and Armenian case but again is unable to cope with the empirical evidence underlying the substitution-effect. The concept of instrumental rationality - disregarding the underlying motivation - may well account for the substitution effect but is not capable to explain expressive acts of terrorism. To summarize, all of the concepts of rationality reach their explanatory limits when it comes to explaining the calculation process of terrorists on empirical grounds.

(B) Correct anticipation of the expected outcome of decisions: Derived from instrumental rationality one can make the assumption that terrorists should be aware of the expected outcome of their actions and should not be caught by surprise. Still this question is hardly touched upon in publications on the rationality of terrorism. 
For the concept of politically rational terrorism, gaining political concessions from their adversaries is not a sufficient condition for rational behavior of terrorists alone. Only if terrorists were anticipating the outcome of their operations correctly, can we speak of instrumental rationality. While instrumental rationality asks individuals to be aware of the outcome of their actions, one might argue that there is hardly any way to know what the reaction of the target will be. Even for an instrumental rationally calculating terrorist, uncertainty remains with regard to the option the targeted government chooses. As a result, the outcome of terrorist actions may deviate from the expected results in the end. Still, instrumentally rational actors are expected to "evaluate how others will react to their moves. This assumes, then, that terrorists will think through possible countermoves that an adversary [...] might make” (Miller, 2009: 9). Instrumentally rational terrorists are thus expected to know what the result of their actions will be.

For the concrete analysis of the rationality of terrorists, the impact of terrorist behavior becomes less important (Josiger, 2009: 79). There is no doubt that terrorists have learned to cause devastating impact both in human toll and economic disruptions with their attacks. Even so, this does not yet qualify for instrumentally rational action as long as it cannot be proven that terrorist groups expected this significant impact to be the result of their action. For the case of al-Qaeda at least, this does not seem to be the case. In a study by Libicki et al. (2007: xv), the authors state that the result of the terrorist attacks of 11 September 2001, conducted by al-Quaeda, and the resulting economic damage surprised the leaders of the terrorist movement, clearly indicating an unexpected outcome of the attacks. This view is shared by Josiger (2009) who emphasizes another facet of the attacks. According to Josiger, the American people did not react the way al-Qaeda had expected. Instead of decreasing support for their own government, as was assumed to be the declared short-term goal of alQaeda, the American population increasingly supported the US government (Josiger, 2009: 80). Similar results are found in a case study on the IRA by Neumann and Smith (2005). The authors state that the IRA tried to make the British government look weak and demonstrate the government's inability to deal with terrorism with their attacks. The terrorist group hoped to alienate the local population from supporting the government this way, but failed. The British population, instead, showed a rising support for tough counter-terrorism measures in the aftermath of attacks (Neumann and Smith, 2005: 587). The same line of argument is found in a study by Lake (2002) on the Oklahoma bombings of 1995 committed by Timothy McVeigh. Lake cites the intention of McVeigh to provoke an overreaction by the government causing civil uprising. Yet, McVeigh misperceived the outcome of his actions and did not 
succeed (Lake, 2002: 20). Still, misperception of the outcome of terrorist actions does not always have to occur. The attacks of Madrid in 2004, committed by al-Quaeda, may in fact present one of the cases contradicting this view. The Madrid bombings had the effect of massively influencing the outcome of the Spanish elections three days later. The newly elected government decided to pull out the Spanish forces out of Iraq shortly there-after. It seems convincing that al-Qaeda correctly anticipated this outcome to occur which highly favored its interests.

Given these examples, there is good reason to believe that the outcome of terrorist acts and behavioral implications "are often beyond the ability of a terrorist group to control or even accurately predict” (McCormick, 2003: 483). As a result, these case studies cast heavy doubt on the assumption of terrorists' complete awareness of the outcome of their actions and contradict instrumental rationality (no matter what the motive) in many cases. The empirical evidence favors the concept of bounded rationality and clearly stresses that the impact of terrorists' actions is often beyond their ability to precisely predict. Bounded rationality may explain why terrorists reach their aspired goals at times by seemingly thorough cost-benefitanalysis, but again often fail to do so due to incomplete information, the use of heuristics and a less than perfect calculation process.

\subsection{Axiom 3: Utility maximizing behavior}

Instrumentally rationally terrorists are expected to choose the option that promises the highest utility for them - be it in political, social or economic terms. To get insight into the question of whether or not such behavior is typical of terrorists, the question of effectiveness of terrorist means is further discussed in the following.

Effectiveness of terrorist means: If terrorists are assumed to act instrumentally rational and if they decide to use violent means, one would expect this means to produce the highest utility available. By implication, terrorism as utility maximizing option is expected to work at least for some of the time. For the case of politically rational terrorism one would hence anticipate that concessions are achieved.

Admittedly, at certain occasions, terrorists may just not have the opportunity and the measures available to accomplish their ultimate political goal. Hamas, for example, has only minor chances of creating a Palestinian state including the complete Israeli territory as a result of their actions. Still, choosing violent measures may still reflect the best choice at hand for 
the group resulting in the best possible outcome but without getting close to the ultimate goal. Terrorist measures would then represent the best choice available and clearly reflect instrumentally rational action. By using a binary distinction of success, however, such gradual levels of success are not captured. The results may thus be biased towards a negative success rate of terrorist groups (see Krause, 2009: 21). ETA might provide an example for this argumentation. While the terrorist group has not managed to achieve the political concession of a fully independent Basque country so far, their violent acts have nevertheless contributed to granting the Basque region a great degree of self-government and autonomy. ETA, this way, has actually managed to have some of their demands met and partly succeeded regarding its ultimate political goal. By using a binary level of success, however, ETA terrorism would be counted as a failure due to missing the ultimate political goal of full independency of the Basque country.

Methods to measure gradual levels of success have already been developed with the OsloPotsdam solution, for instance, which allows determining success in a standardized interval from 0 to 1 (Hovi et al. 2003: 75 et seq.). With the aid of this method it would be possible to determine gradual levels of success of terrorist action and let go of binary based models. This way all terrorist achievements could be grasped.

Still, binary based argumentation to determine terrorist effectiveness is widely applied in the academic literature and reflects a pragmatic and feasible approach to gain insight into the effectiveness of terrorist actions. Even this way, one should still be able to make useful remarks on whether or not terrorism works while acknowledging that gradual levels of success are left out of the analysis. Despite its limitations, a binary coding - only differentiating between a complete success and failure - will hence also be used in the further discussion. Even under the premise of a binary success model, terrorist groups should be expected to succeed at times at least. Evidence suggesting a complete failure of terrorists to accomplish the aspired goals would point towards irrational or boundedly rational behavior. The question of how effective terrorism really is has caused widespread attention in the academic field. Interestingly, the answers given highly diverge. Prominent authors such as Robert Pape, Alan Dershowitz, Andrew Kydd and Barbara Walter, for instance, find supporting evidence for the assumption that terrorism works. Terrorists, according to their results, manage to achieve the political ends they pursuit. However, scholars like Max Abrahms, Assaf Moghadam, Brian Michael Jenkins and Dipak Gupta reject these results. They consider terrorists to fail widely when it comes to accomplishing political goals. Terrorism as a means would then become irrational. To shed some light into this highly 
controversial discussion, one has to begin with asking what it is that terrorists really want. Only this way can we learn more on the effectiveness of the means used by terrorists. Since most of the academic discussion is on the effectiveness of politically motivated terrorists, the concept of politically rational terrorism promises to be a good starting point for analysis.

According to Frey and Luechinger (2007: 225), terrorists try to achieve three main political objectives: (1) Terrorists seek media and public attention to gain support; (2) Terrorists seek to destabilize political systems to successfully bring about political change; (3) Terrorists seek to damage the economy of an adversary.

Yet these objectives need to be classified as residing rather on the tactical level. Except for the second stated objective, these objectives do not represent ultimate goals in themselves, but means or short-term goals towards accomplishing the ultimate goal of political change. On the tactical level, one might add efforts to generate support within the local population by provoking governments into brutal and indiscriminate counter-terrorism action as terrorist means (Target overreaction) (Merari, 1993: 233; Neumann and Smith, 2005: 580; De Mesquita and Dickson, 2007: 364 et seq.). Moreover and contrasting the means of target overreaction, terrorists might use violence within a strategy of power deflation, also labeled as strategy of chaos (Merari, 1993: 234). Using this strategy, terrorists try to make the targeted government look weak and demonstrate the government's inability to deal with terrorism (Merari, 1993: 234; McCartan et al., 2008: 62).

In contrast to short-term goals or tactical means, ultimate goals necessarily include a political intention. While generally concentrating upon a "fundamental change in the power relationship within a society” and broadly reflecting some sort of political issue, ultimate goals vary widely depending on the terrorist group (Gupta, 2008a: 186). ”The nationalist want independent states; the communists the end of the capitalist system; and the religious fundamentalists a society built around their own interpretation of the scripture” (ibid.). The question remains whether terrorists have managed to accomplish these ultimate goals.

Dershowitz (2002: 2) finds terrorist action to be extensively effective. His analysis, however, completely rests on the Palestinian case. The author considers bringing attention to the Palestinian case and inspiring Palestinians to commit further acts of terrorism as a success of terrorist attacks, which makes terrorism a rational decision for him (Dershowitz, 2002: 26). Yet, such argumentation can hardly be brought in line with the long-term political goals that were defined as condition for politically rational terrorism. His findings rather reflect the accomplishment of short-term goals such as gaining support or media and public attention. Palestinian terrorist groups such as Hamas can, however, be thought of as aiming at the 
creation of an independent Palestinian state or at destroying Israel (and maybe a combination of both) as their ultimate goal (Ganor, 2008: 276; Piazza, 2009: 66). Yet, Hamas has not made any progress with regards to this goal.

Another prominent author claiming terrorism and especially suicide terrorism to be effective and to work is Robert Pape. For his analysis, Pape refers to terrorist groups that used suicide tactics as part of their campaigns. He comes to the conclusion that for a high number of these campaigns, terrorists were found to have succeeded and that suicide terrorism thus works (Pape, 2003: 1 et seqq.). Yet, his findings have come under criticism regarding the selection of case studies and methodological issues. In Pape's study, the underlying sample produces a 54 percent success rate of terrorist campaigns which included suicide attacks. Yet, this number has been denoted as being highly exaggerated and only resulting from a biased case selection (Moghadam, 2006: 713).

Kydd and Walter (2006) argue in line with Pape and try to demonstrate that terrorism indeed works. Analyzing a number of case studies they find similar results to those of Pape and take it as supportive evidence for the rationality of terrorists (Kydd and Walter, 2006: 49). Further findings supporting the view that terrorism works can also be found elsewhere (see Lake, 2002: 21; Oberschall, 2004: 31; Victoroff, 2005: 16). To summarize, a considerable number of authors regard terrorist behavior and the impact of terrorist action as proof that terrorism works and that terrorists are thus instrumentally rational actors.

Effectiveness and instrumental rationality of terrorist action is, however, challenged by various scholars, including Abrahms (2004, 2006, 2008), Jenkins (2006) and Gupta (2008a). As one of the prominent opponents of the concept of instrumentally rational and politically motivated terrorism, Abrahms challenges the data used as the basis for determining the success of terrorism. According to his analysis, studies claiming terrorism to be effective, are based on a few selectively chosen case studies (Abrahms, 2006: 45). In a study of 2006, Abrahms analyses the twenty-eight groups specified in the list of foreign terrorist organizations by the U.S. Department of State since 2001 with regards to their success in accomplishing their politically stated goals. Abrahms finds that the terrorist organizations accomplished their political goals in only seven percent of all cases (Abrahms, 2006: 44). His study was, however, criticized on "assess[ing] success towards objectives with the largest scale” which may account for the low number of successful terrorist incidents (Krause, 2009: 21).

Evidence challenging the concept of instrumental rationally terrorists can also be derived from the work of Libicki et al. (2007). In a case study on the terrorist attacks committed by al- 
Qaeda, the authors analyze fourteen terrorist incidents from 1991 to 2004 (Libicki, et al. 2007: xv). Underlying the analysis is the assumption of al-Qaeda aiming at the creation of an Islamic caliphate combined with driving Western influence and presence out of the Islamic region as their ultimate political goal (Libicki, et al. 2007: xiii; similarly stated in Roy, 2008: 4). While the impact of the attacks of al-Qaeda have often proven to be significant ${ }^{19}$, they have in fact hardly helped the terrorist movement to accomplish the aspired political goal.

To summarize, there is convincing evidence that politically rational terrorists often succeed in accomplishing their short-term goals such as international (media) attention and causing disruption and economic damage (Merari, 1993: 237 et seq.; Jenkins, 2006: 126; Gupta, 2008a: 191;). Yet, these achievements should be seen as means towards achieving the strategic (long-term) goal of political change than ends in themselves. Terrorists, however, hardly if ever reach these strategic goals (Abrahms, 2004: 537; Jenkins, 2006: 129; Gupta, 2008a: 191). "The overwhelming majority of the many hundreds of terrorist groups which have existed in the second half of this century have failed miserably to attain their declared goal” (Merari, 1993: 237). This empirical evidence challenges the utility maximizing principle, which is expected to be underlying the decisions of instrumentally rational terrorists.

Does a variation of motives of the concept of instrumental rationality enhance the explanatory power of the concept? Have terrorists been successful with regards to social or economic goals?

Drawing on the concept of economically rational terrorism, a number of terrorist acts, ${ }^{20}$ which have inflicted considerable damage both in human lives and in economic terms apparently prove the effectiveness of terrorism. Killing 3.000 people and causing approximately $\$ 20$ billion as direct costs only of economic damage, can certainly be considered to be a significant impact of the attempt of 11 September 2001 (Jenkins, 2006: 129). Furthermore, it was found that terrorists often tend to achieve their short-term goals including disruption and economic damage. But there are plenty of examples where terrorism did not cause any significant economic damage at all. If terrorists actually were regularly trying to cause maximum economic damage, why is it then that for al-Qaeda, for instance, such objectives seem to have played only a specific role in a minor part of their attempts (see Libicki, 2007: 48). Why have most terrorists refrained from using Weapons of Mass Destruction if they could have caused more damage this way and increased their utility?

\footnotetext{
${ }^{19}$ Compare the attempt 11 September 2001 in New York and Washington causing a high number of casualties.

${ }^{20}$ Compare the bombings in Madrid (2004), London (2005) and the suicide attack on the oil tanker MV Limburg in 2002, for instance. For an elaboration on these terrorist incidents see Libicki et al. (2007).
} 
The presented evidence further challenges the motive of self-enrichment. Terrorists who strive for personal enrichment - similarly to criminals - do not have a strong interest in gaining public attention and putting themselves at risk of persecution. Major terrorist attacks, however, have exactly had this effect without producing noticeable economic benefits for terrorists.

The concept of socially rational terrorism reveals its inherent limitations as well when confronted with high-profile attacks. Since "group security (...) is inversely related to the scale and dramatic quality of its attacks” (McCormick, 2003: 496), high-profile attacks ${ }^{21}$ increasingly endanger the operational capacity of terrorist groups and threaten the survival of a group as social unit. Socially rational terrorism can hence hardly be declared compatible with the actions of terrorist groups such as al-Qaeda, which has committed high-profile attacks and killing thousands of people instead of limiting their actions in size and degree. The attacks certainly did not contribute to secure the affective ties of the group members but instead endangered the survival of the group. Social motivation, as a consequence, seems to be inadequate to explain all terrorist behavior.

Concepts of irrationality can claim to explain those cases, where instrumentally rational terrorists failed to accomplish their goals. Still, it can only account for a part of all terrorist actions. The available empirical evidence lends support to the conclusion that bounded rationality offers an approach to explain all terrorist behavior. Bounded rationality can both account for situations in which terrorists accomplished to reach their goals but can also explain why terrorists fail to do so, due to a limited cost-benefit analysis and a limited ability to predict the outcome of actions.

To summarize, the provided empirical cases speak against the validity of other than political or economic motives. At the same time, terrorists neither seem to act instrumentally rational nor irrationally with regard to political motives when it comes to choosing the best option available. Rather, the concept of bounded rationality may account for most of the presented empirical evidence.

\subsection{Axiom 4: The concept of methodological individualism}

As a final axiom, methodological individualism serves as a criterion to test the rationality of terrorists. In more detail, the following analysis is on the consistency between the individual and collective levels.

\footnotetext{
${ }^{21}$ Compare the attacks in New York and Washington on September 11, 2001 for instance.
} 
Consistency between the individual and collective levels: The distinction between the different structural levels of terrorist organizations has been explicitly left out so far in the previous discussion. It remains to be evaluated whether concepts of rationality can explain actions and behavior for all levels of terrorist organizations. Based on the principle of methodological individualism as a crucial factor of Rational Choice Theory, this is exactly what is to be expected from an instrumentally rational approach. Evidence of different levels of rationality within a terrorist group, however, would cast heavy doubt on the explanatory power of concepts of instrumental rationality to explain all terrorist behavior.

Terrorist actions may be rational at one level of analysis but irrational on another. Only by looking closer at the inner life of terrorist groups can we learn more on this aspect. For pragmatic reasons, a distinction will only be made between the individual terrorist and the collective terrorist group represented by its leader - although further distinctions are easily conceivable $^{22}$ (Pittel and Rübbelke, 2009: 2). Turning to empirical cases, it turns out that the degree of rationality may indeed vary between the different levels of terrorism:

Firstly, one can think of situations in which terrorist action is instrumentally rational on the individual level but not contributing to the success of the terrorist group making such decisions irrational on the group level. Miller (2009) cites the Oklahoma City Bombing of 1995 as supporting evidence. Timothy McVeigh as the central acting terrorist may have considered the attacks as success on a personal level. However, McVeigh was also linked to extremist militia groups. As the American population showed increasing support for the US government in the aftermath of the attacks, this outcome was counterproductive with regard to the aim of weakening the US government for the extremist militia groups (Miller, 2009: 16). This example points to a general characteristic of terrorist organizational structures. Depending on the structure of a terrorist group, the leaders of those groups will be more or less able to control their followers and prevent them from actions, which may not be in the interest of the group as a whole.

In the literature, a main distinction is made between hierarchical and decentralized terrorist groups (De la Corte, 2007: Section seventh principle; n. pag.). Within hierarchical structures, the leader of a group acts as central authority, which allows him extensive control of the group (Eilstrup-Sangiovanni and Jones, 2008: 12; Miller, 2009: 15). In general, terrorist groups predominantly active in the 1970s and 1980s such as the IRA and the German Red Army Faction (RAF) are examples of such traditional groups (Hoffman, 1999: 8). The

\footnotetext{
${ }^{22}$ See for instance Miller, 2009: 4, who further introduces the level of terrorist movements.
} 
followers of the group are made sure to follow the orders of the leader who dictates decisions and rules (Dishman, 2005: 241). As a direct consequence, rational decision-making is expected as long as the leader acts rationally (Moore, 2005: 11; Miller, 2009: 15).

Decentralized structures may still feature a certain degree of command structures. The organizational concept of a decentralized cell structure, for instance, takes the form of a network with various leaders, so that no single leader is in command of crucial decisions (Dishman, 2005: 242; Eilstrup-Sangiovanni and Jones, 2008: 12). The new Islamic terrorism and jihadist networks inspired by al-Qaeda ideology are good examples of this structure (De la Corte, 2007: Section seventh principle; n. pag.). In decentralized cell structures, decisions made may deviate from the ultimate goal of the group to some degree and be less consistent due to personal interests of leaders. This makes decisions of the group, as a whole, less rational (Miller, 2009: 15). As another form of decentralization of terrorist groups, leaderless structures may evolve, where no leader controls decisions made. Instead, an individual or a small group commits terrorist attacks independent of leaders or networks (Dishman, 2005: 243). What follows is a complete lack of control of the actions of single members, so that actions of single members will hardly be in line with the ultimate goal of the group any more (Miller, 2009: 15).

The structure of terrorist organizations has implications for both the line and coherence of command but also for the vulnerability of the organization. Hierarchical groups show a high degree of consistency with regard to the decisions taken within the group, so that the goal of the group is submissively pursued by order of the leader (De la Corte, 2007: Section seventh principle; n. pag.). Such a clear command structure is missing in decentralized terrorist organizations where the leaders will only be poorly informed about the behavior of their followers. Decisions taken within those groups are thus bound to show a lesser degree of consistency and varying degrees of rationality within the group will not be compensated by a strict hierarchical order (Miller, 2009: 6). “As a result, resources may be used poorly, contradictory tactics selected, and activities carried out that serve parochial short-term interests rather than the larger mission” (Eilstrup-Sangiovanni and Jones, 2008: 21). Moreover, a lack of control and information asymmetries may also create moral hazard problems for leaders. Followers of a group acting as agents may be inclined to divert money from its intended use due to a lack of observation and control (Shapiro, 2006: 4). Still, decentralized structures and leaderless concepts of organization in particular also make those organizations less vulnerable for state persecution than is the case for centralized groups (Schneckener, 2006: 191; Miller, 2009: 15). In reality, most terrorist organizations show 
characteristics both of cell structure and hierarchical elements, so that the distinction previously stated is only an ideal type of group classification (Mayntz, 2004: 11).

Secondly, situations may occur, in which decisions of terrorists are seemingly instrumentally rational on the group level but not on the individual level. A terrorist group may highly benefit from certain actions, while on the individual level, such action is proof of irrational action. One of the often cited examples of this constellation is the case of suicide bombings, which certainly is a puzzle for instrumental rationality. Suicide bombings on the individual level apparently prove irrational or boundedly rational behavior at best. Suicides bombers are described as 'lone, irrational fanatics’ (Sprinzak, 2000: 72), and their acts as 'self-destructive, not selfinterested’ (Caplan, 2006: 96).

Researchers have tried to prove instrumental rationality of suicide bombers with a modification of their cost-benefit configuration (Enders and Sandler, 2002: 7). Still, such analysis is always confronted with one major obstacle; no matter how much benefit such action is assumed to generate, the costs of killing oneself is presumably always higher making suicide attacks an irrational action on the individual level (Hafez, 2006: 169; Richardson, 2006: 33). Rewards in the afterlife as crucial beneficial element for suicide bombers can also be rejected, since suicide bombings are not limited to religious extremists but occur worldwide (Pape, 2003: 1).

Suicide bombers thus hardly act according to the concept of instrumental rationality but rather they seem to act irrationally, striving for goals such as fame or revenge (Pronin et al., 2006: 385). Alternatively, suicide bombers may be assumed to miscalculate costs and benefits of their operations. In their view they might take a rational decision. This would point towards bounded rationality.

While suicide bombings on the individual level indicates a deviation from instrumental rationality, scholars widely agree that this does not have to be the case for all levels. From the perspective of a terrorist group, such actions may actually be instrumentally rational (Pape, 2003: 2; Richardson, 2006: 33; Miller, 2009: 5; Pittel and Rübbelke, 2009: 1). Suicide bombings offer specific advantages over other means, presenting low-cost operations that both have a significant psychological impact and inflict a high number of casualties (Sprinzak, 2000: 66; Hafez, 2006: 166). Suicide attacks have been found to cause many more casualties than does a conventional act and appear to be an attractive option and instrumentally rational means for terrorists on the group level (Pape, 2003: 5).

To summarize, it was shown that the degree of rationality between the individual and collective levels of terrorists may indeed vary. This evidence speaks against the universal 
validity of concepts of instrumental rationality regardless the underlying motivation. Neither does an irrational concept account for all actions. Again it seems that a concept of bounded rationality provides the missing link to account both for cases of seemingly irrational and instrumentally rational behavior. Taking the example of suicide terrorism, the decision of suicide bombers to commit an attack may be seen as the result of miscalculation, while suicide terrorism on the group level may be the result of a precise cost-benefit analysis even if based on heuristics. Admittedly, it doesn't seem realistic to always think of suicide bombers as miscalculating while group leaders are assumed to always precisely calculate with the use of heuristics or the satisficing principle. This limits the explanatory power of the concept of bounded rationality.

\subsection{Discussing the results}

There is no doubt that the previous discussion has not considered all possible arguments of terrorist rationality but still the results provide informative insight.

In contrast to the widespread assumption underlying many studies on terrorist behavior, terrorists often seem to deviate from instrumentally rational behavior or alternatively seem to be motivated by other than political motives. While the concept of instrumental rationality clearly lacks explanatory power for at least parts of terrorist behavior, neither does the concept of irrational behavior explain all terrorist actions. Bounded rationality might provide the missing link to account both for apparently irrational behavior but also for thoroughly calculated means to reach political goals. Still, limitations were also found for a bounded rational approach when trying to account for all terrorist behavior. With a variation of the underlying motive of the concept of instrumentally rational and politically motivated terrorism, it became instantly clear that, beyond that, none of the discussed concepts provides sufficient explanatory power to explain all terrorist behavior. Based on the motives of terrorists and the perceived rationality the results of the previous discussion are summarized in Table 3.

This thesis does not aim at quantifying the explanatory power of all concepts. Instead, by illustrating the limited explanatory power of the concept of politically rational terrorism to explain all terrorist behavior, the necessity is stressed for alternative concepts both varying in motivation and degree of rationality to be considered as viable alternatives. 
Table 3: Explanatory Power of the Concepts of Rationality

\begin{tabular}{|c|c|c|c|c|c|c|c|}
\hline & & \multicolumn{6}{|c|}{ Assumption } \\
\hline & & $1 \mathrm{~A}$ & $1 \mathrm{~B}$ & $2 \mathrm{~A}$ & $2 B$ & 3 & 4 \\
\hline \multirow{6}{*}{ } & $\begin{array}{l}\text { Instrumentally rational } \\
\text { and politically } \\
\text { motivated }\end{array}$ & $\begin{array}{l}\text { Partly at } \\
\text { most }\end{array}$ & Partly & Partly & Partly & Partly & Partly \\
\hline & $\begin{array}{l}\text { Instrumentally rational } \\
\text { and economically } \\
\text { motivated }\end{array}$ & Yes & Yes & $\begin{array}{l}\text { Partly } \\
\text { at most }\end{array}$ & $\begin{array}{l}\text { Partly } \\
\text { at most }\end{array}$ & Partly & $\begin{array}{l}\text { Partly } \\
\text { at most }\end{array}$ \\
\hline & $\begin{array}{l}\text { Instrumentally rational } \\
\text { and self-enriching }\end{array}$ & Yes & Yes & $\begin{array}{l}\text { Partly } \\
\text { at most }\end{array}$ & $\begin{array}{l}\text { Partly } \\
\text { at most }\end{array}$ & $\begin{array}{l}\text { Partly } \\
\text { at most }\end{array}$ & $\begin{array}{l}\text { Partly } \\
\text { at most }\end{array}$ \\
\hline & $\begin{array}{l}\text { Instrumentally rational } \\
\text { and socially motivated }\end{array}$ & Yes & Yes & $\begin{array}{l}\text { Partly } \\
\text { at most }\end{array}$ & $\begin{array}{l}\text { Partly } \\
\text { at most }\end{array}$ & $\begin{array}{l}\text { Partly } \\
\text { at most }\end{array}$ & $\begin{array}{l}\text { Partly } \\
\text { at most }\end{array}$ \\
\hline & Boundedly rational & $\begin{array}{l}\text { Partly at } \\
\text { most }\end{array}$ & Partly & Partly & Yes & Yes & (Yes) \\
\hline & Irrational & Partly & Partly & Partly & Partly & Partly & Partly \\
\hline
\end{tabular}

With this conclusion, a spectrum of terrorist behavior appears to be a convincing alternative to the concept of politically rational terrorism only. This has serious implications for counterterrorism measures which will be further discussed in the next chapter. 


\section{Implications for counter-terrorism policy}

With the results from the previous discussion in mind, this chapter is on the implications for counter-terrorism policy. The aim is to identify counter-terrorism measures for the spectrum of motivations and levels of rationality of terrorists.

\subsection{Emphasizing the need for a spectrum of counter-terrorism measures}

In line with the academic focus on instrumentally rational and politically motivated terrorists, suggestions for counter-terrorism have predominantly been formulated for this very concept. As was shown before, however, it may be too narrow-minded to just rely on terrorists always acting instrumentally rational and always striving for political goals.

Taking into account that all of the introduced concepts of rationality and motivation proved capable of explaining some facets of terrorism only, generating a spectrum of counterterrorism measures derived from the concepts of terrorist rationality and motivations seems to be more adequate. The aim is to find appropriate counter-terrorism strategies for every introduced concept of terrorist rationality and to find out whether there is common ground for these strategies.

Before discussing appropriate counter-terrorism strategies, it is important to stress again that the underlying concepts represent an ideal type of classification. In reality, one may often be faced with terrorist groups mingling various objectives and deviating from the expected means. For the following discussion, however, a reference to the ideal types of concepts allows to clearly identify whether the counter-terrorism measures at hand have a great deal in common or differ widely.

\subsection{Deriving counter-terrorism strategies}

For states, the first choice to make is to judge whether or not terrorists are rational actors. If terrorists are perceived as instrumentally or boundedly rational actors, policies based on manipulating the utility function of terrorists may well work, while such policies will clearly be excluded when dealing with irrational terrorists (Moore, 2005: 4). Instrumentally rational terrorists in particular are prone to a manipulation of their cost-benefit-calculations. Counterterrorism measures may succeed when targeting the utility terrorists derive from their acts. 
These measures may aim at deterring terrorists from committing violent acts either by raising the costs of terrorism or by minimizing the political benefit of such acts for terrorists in order to reduce the acts of terrorism (Sederberg, 1995: 303; Frey and Luechinger, 2002b: 5 et seqq.). Rising costs for terrorists to conduct violent acts, may be the result of enhanced security measures, fortifying potential targets such as critical infrastructures and more severe punishment. Such measures make it both harder and more dangerous for terrorists to commit acts of violence (Arce and Sandler, 2005: 184; Moore, 2005: 5). The result in economic terms is a shift of the supply curve (see Fig. 2), representing the costs of terrorist acts.

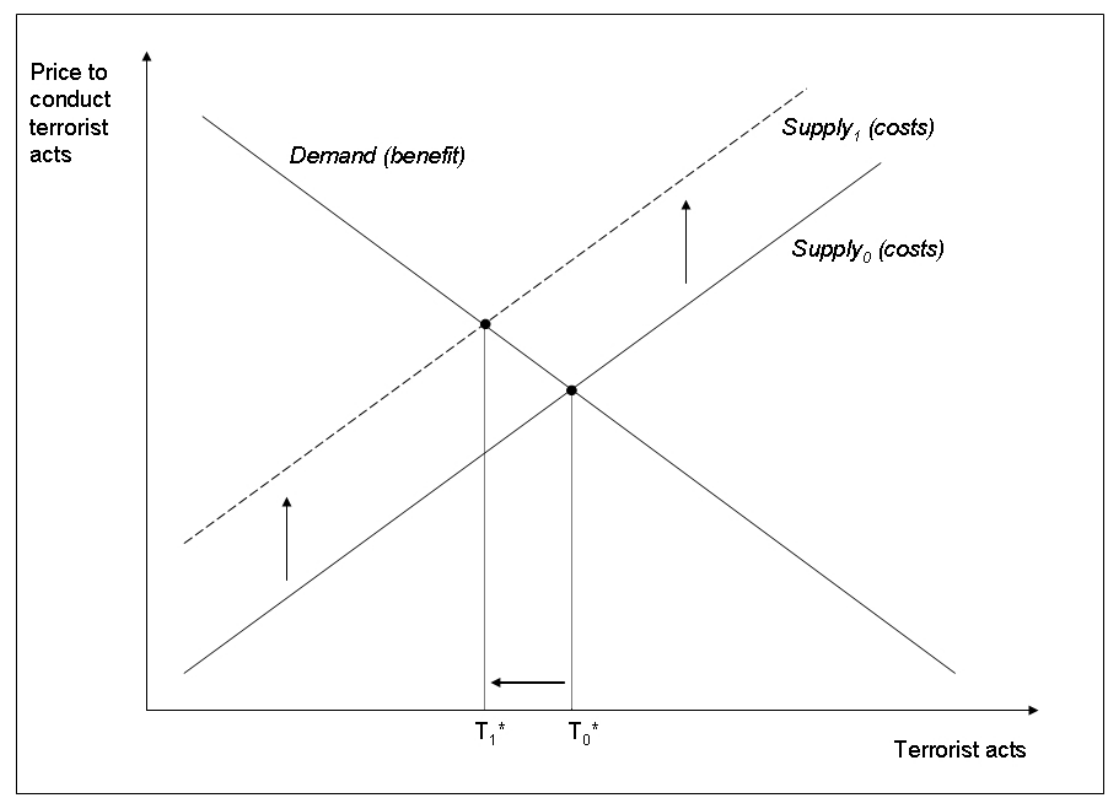

Fig. 2: Increasing the Costs of Terrorism (Income Effect) Source: See Frey, 2008: 214;

A reduction of benefits, in contrast, is represented in Fig 3 by shifting the demand curve downwards. Frey and Luechinger (2007) suggest a decentralizing policy, distributing political and economic power between several centers of decision-making as conceivable measure to reduce the impact of terrorist attacks and hence the benefit for terrorists (Frey and Luechinger, 2007: 227). Such a policy, however, seems difficult to realize, since extensive structural changes on the governmental level would be necessary.

The shift of supply curve and demand curve are described as income effect, since the income (resources) of terrorists is affected in total (Enders and Sandler, 2002: 2). 


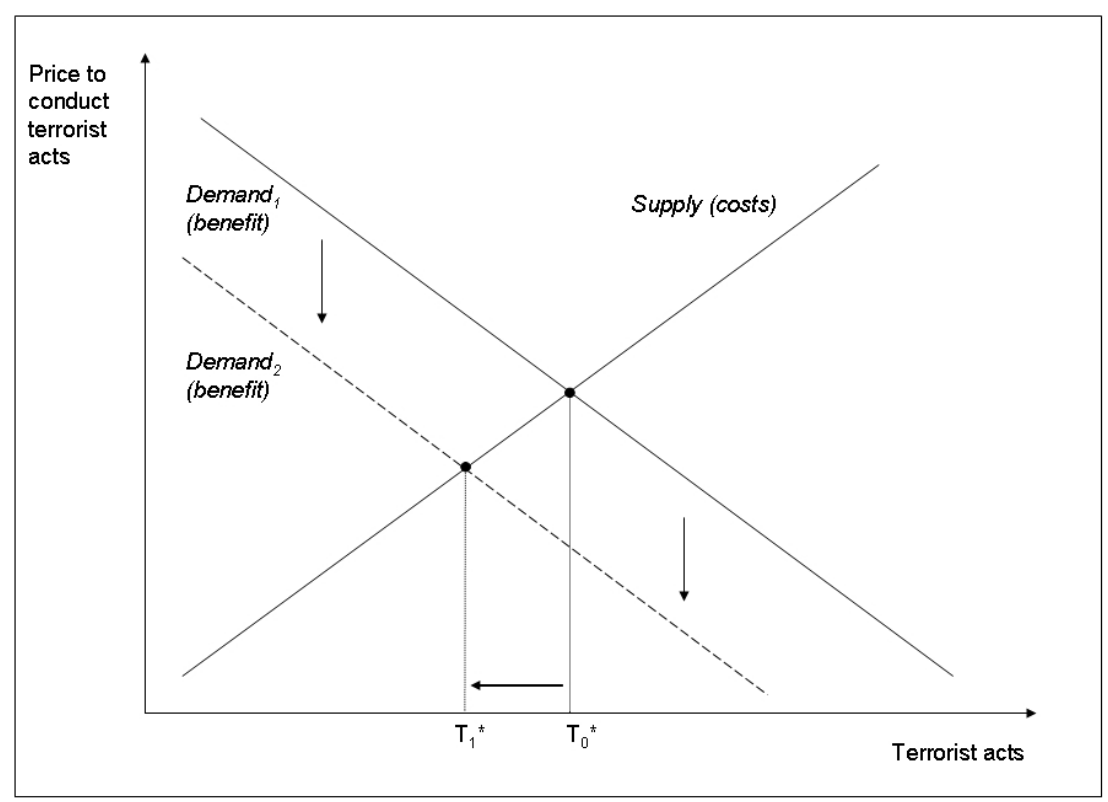

Fig. 3: Reducing the Benefits of Terrorism (Income Effect) Source: See Frey, 2008: 215;

While an increase of costs for terrorists through better protection and tougher punishment is expected to be applicable for every instrumentally rational terrorist group, measures to decrease their utility, in contrast, need to explicitly aim at the concrete political, social or economic goal of a group.

If government action does not increase the costs of all terrorist operations or at least a wide range of terrorist attack modes, the result will not be an overall income effect for terrorists but a relative increase in costs to conduct specific operations. Under the assumption of instrumentally rational terrorists, the result will be a substitution effect instead of an income effect taking place. Terrorists are expected to substitute into less costly operations (Enders and Sandler, 2002: 2; Enders and Su, 2007: 45).

The same is true for a government policy that reduces the benefit of some operations available to terrorists, only. While terrorists might indeed substitute into non-violent measures (Shugart, 2006: 11; Krebs, 2009: 6), there is also a high chance, that terrorists adapt by "changing the time of attack, by changing the mode of attack, by changing the capital-intensity of attack, by changing the lethality of attack, by changing the location of attack" and continue to use violent measures (Brauer, 2006: 10). Seen in economic terms (see Fig. 4), a case of two goods is needed to illustrate the substitution effect. While only terrorist activities were analyzed before, both terrorist activities and other activities ${ }^{23}$ are referred to in the following. Based on

\footnotetext{
${ }^{23}$ Other activities may actually also contain specific terrorist measures, which do not become more costly for terrorists to conduct, after governmental measures have been applied. These options are not included within Terrorist activities. As a result, a substitution of Terrorist activities does not necessarily have to reduce the number of terrorist attacks.
} 
micro-economic theory, the intersection of budget constraint ${ }^{24}$ and indifference curves ${ }^{25}$ displays the equilibria $\mathrm{T}_{0 / 1}^{*} \mathrm{O}^{*}{ }_{0 / 1}$ of terrorist and other activities chosen. The substitution effect does not result in a complete shift of supply or demand curve, but the budget constraint is assumed to pivot, since only terrorist activities $\mathrm{T}$ are becoming more expensive to conduct. The new equilibrium of terrorist and other activities is then $\mathrm{T}_{1} / \mathrm{O} *_{1}$.

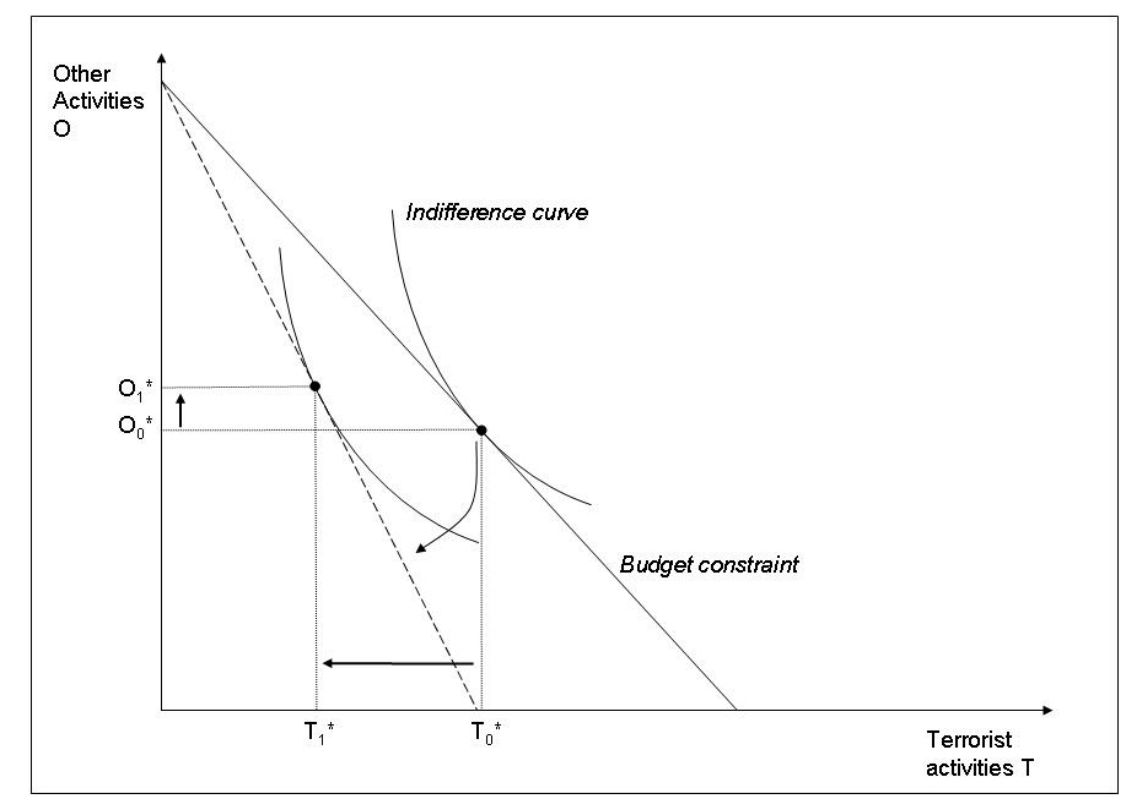

Fig. 4: Increasing the Costs of Terrorism (Substitution Effect)

Bounded rational terrorists may also substitute into less costly activities at times. But it is also conceivable that they fail to do so and stay with their less than perfect option. They may perceive this primarily chosen option as best one available, due to an incomplete or flawed calculation process. In total, it remains hard to predict how bounded rational terrorists are going to act, which makes it difficult to find appropriate counter-terrorism measures.

Deterrence does not only present a viable option for engaging politically motivated terrorists. The model of utility maximization and a derived possible manipulation of costs and benefits of individuals are not limited to the political realm; utility can also reside in economic or social factors.

Instrumentally rational terrorists striving for personal enrichment as the ultimate goal of their actions are prone to a manipulation of their utility in the same way. For those groups in particular, freezing terrorist finances may be a promising strategy to target the nerve of their operational system. By denying terrorists what they most eagerly strive for, they may

\footnotetext{
${ }^{24}$ A budget constraint describes the income (resources) available to an individual for all combinations of the two given goods (Gupta, 2008: 207).

${ }^{25}$ An indifference curve measures different quantities of two goods, which provide an individual with equal utility. The individual is thus indifferent between these combinations of the goods (Gupta, 2008: 207).
} 
reconsider turning to non-violent means. Scholars have suggested that counter-terrorism measures combating self-enriching terrorists can and should not be separated from the fight against organized crime (Sanderson, 2004: 58). "Crime analysis must be central to understanding the patterns of terrorist behavior and cannot be viewed as a peripheral issue. [...] [A] broader view of today's terrorist and criminal groups is needed, given that their methods and their motives are often shared” (Shelley et al., 2005: 7).

Deterrence is also expected to work to keep economically rational terrorists from committing acts of violence. Still, economically rational terrorists should be clearly separated from rationally self-enriching terrorists, so that strategies here should not be mingled with combating organized crime.

Efforts to deny the utility of socially rational terrorists by raising costs or reducing benefits of conducting operations may, however, also have a countervailing effect. Deterrence alone is likely to intensify the bonds within the group and not to help to weaken or even dissolve such groups (Moore, 2005: 13). Tougher punishment and repression as a form of deterrence hence do not seem to be an optimal counter-terrorism strategy to combat socially rational terrorists. Rather, deterrence needs to be combined with other measures. Since the major goal of these terrorists is to keep their group alive from a group-perspective and to intensify bonds with other members from an individual perspective, counter-terrorism strategies have to adapt to these objectives.

If individuals indeed derive utility from social contacts within their group, the best countering measure to be chosen may consist in infiltrating the group, producing tension within the group and deny terrorists this social utility. Offering alternatives to terrorists which promise a perceived higher utility ${ }^{26}$ may facilitate them to leave these groups. Members willing to leave terrorist groups and providing valuable intelligence may be rewarded by offering financial compensation or reduced punishment (Frey and Luechinger 2002b: 12; Moore, 2005: 13). Instead of targeting terrorists group as a whole, measures targeting instrumentally rational and socially motivated terrorists are rather assumed to work when aiming at individual members of these groups. With single members of the group leaving and cooperating with public authorities, the social benefit for the remaining terrorists' will be reduced by breeding mistrust and exposing them to the risk of persecution at the same time (Moore, 2005: 9; Abrahms, 2008: 105). "Nobody knows who will succumb to the outside attractions and become a "traitor!" by leaving the group. This diminishes the effectiveness of the group" (Frey and Luechinger, 2002b: 9).

\footnotetext{
${ }^{26}$ Such an approach is conceptualized as raising the opportunity costs of terrorists by Frey and Luechinger (2002b).
} 
Still, this strategy faces the major problem of probably leaving the more radical elements of a terrorist group in command, which are less prone to incentives from the outside. "When governments offer concessions to an ideologically heterogeneous terrorist organization it is the moderates within that organization who are most likely to accept the concessions.” Consequently, the terrorist organization is left in the hands of extremists and the number of terrorist attacks may even increase (De Mesquita, 2005: 146).

Deterrence might also fail in case terrorists do not act according to instrumental rationality but irrationally choose what to do (Sederberg, 1995: 305; Caplan, 2006: 101; Miller, 2009: 2). Terrorists in this case may not be influenced by incentives from the outside, so that they "neither react to cost nor to rewards for their actions" (Frey and Luechinger, 2002a: 5). In economic terms (see Fig. 5), the supply curve would be vertical, so that strategies adopted by the state to influence terrorists (compare the shift of the demand curve) would not diminish the number of terrorist attacks (ibid.).

Both for irrational and instrumentally rational terrorists a prediction can thus be made whether or not deterrence is expected to work. For bounded rational terrorists, however, such a prediction is difficult to make. They might be approached by using the deterring mechanism applied towards instrumentally rational terrorists and at times such an approach might indeed work. Still, uncertainty remains, since bounded rational terrorists might also show seemingly irrational behavior due to a lack of information or an imperfect calculation process. Consequently, no clear answer can be given whether deterrence represents an adequate method to approach bounded rational terrorists.

Instead of deterring terrorists, governments may also choose to bargain. Bargaining with instrumentally rationally terrorists seems promising and giving in to political or economic concessions may still be a cost-effective way for governments "when the costs of those concessions [...] are less than the costs of continued efforts at deterrence” (Moore, 2005: 13). Still, bargaining may only work under certain premises. Regarding political motivation it was already stated that offering concessions is expected to work. This is true both for the traditional type of politically rational terrorism but also for the new (Islamic) terrorism. With the non-discriminating mode and the rising number of casualties resulting from attacks of the new terrorism (Hoffman, 1999: 10; Picco, 2005: 75), selected means of terrorists seem to approach economically rational terrorism. Still, political motives remain prevalent even for the new terrorism, so that bargaining is expected to be a viable option. 


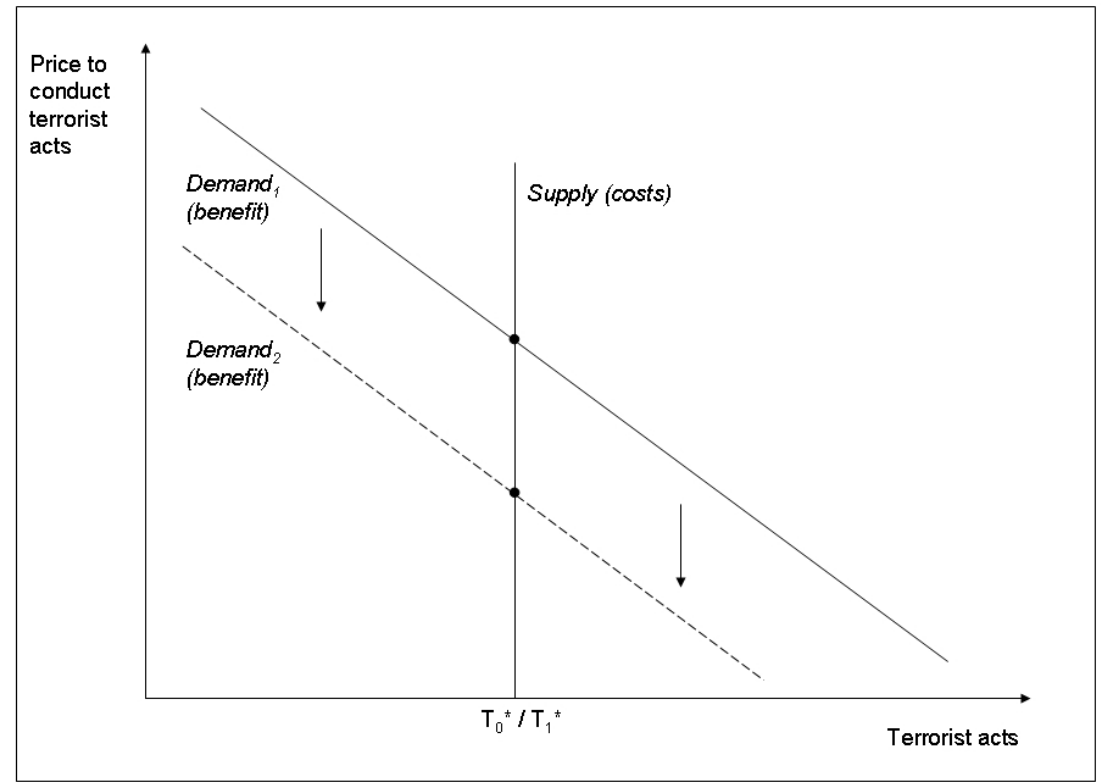

Fig. 5: Reducing the Benefits of Terrorism for Irrational Terrorists (Income Effect)

The same is true for the case of instrumentally rationally terrorists motivated by goals of selfenrichment. Instead of offering political concessions, the behavior of these terrorists may be altered by offering financial compensation. Yet the danger emerges that giving in to the demand of terrorists may result in further demands being formulated.

Bargaining may fail for alternatively motivated terrorists. With economic disruption presenting an end in itself for some terrorists, states cannot make any meaningful concessions. For those groups, deterrence seems to be the only working principle. It remains uncertain as well, whether socially rational terrorist groups, as a whole, may be convinced to turn to nonviolent means or dissolve their group by the offer of concessions. While single members may be prepared to leave those groups, governmental concessions will hardly affect the social utility terrorists derive from being a member of a terrorist group.

Moreover, bargaining with irrational terrorists needs to be rejected as a viable option, since irrational terrorists will not be prone to a manipulation of their cost-benefit-structure. Caplan (2006: 102 et seq.), instead, suggests using persuasion and appeasement as possible options to engage irrational terrorists. Persuasion may work by targeting feelings of irrational actors instead of facts, while appeasement may stop irrational terrorists by giving in to symbolic demands. Contrary to a rationally calculating actor, an irrational terrorist may not calculate what is in for him and feel satisfied with only limited concessions granted.

Again, bounded rational terrorists are a major puzzle for the development of concrete counterterrorism measures. It was stated before that these terrorists may both make instrumentally rational decisions but also decisions that are best described as irrational. Bargaining may thus 
fail to work, if bounded rational terrorists do not react to offered concessions as expected. Whether or not to bargain here is thus hard to tell.

Both bargaining and deterrence are faced with a central problem. Terrorist groups may show a differing degree of rationality on different levels, as was discussed in the previous chapter. Deterring instrumentally rational leaders of a group may well work, while efforts to deter an irrational follower, willing to commit a suicide attack, will most probably fail (Fisher, 2006: 4). Governmental strategies aiming to deter groups as a whole may hence only work in case that (a) the leader of this group, at least, behaves instrumentally rational and the targeted terrorist group is cohesively organized and hierarchically structured or (b) the group is organized de-centralized but instrumental rationality is given on all levels (Miller, 2009: 19). The same implication holds true for the case of bargaining. Bargaining with terrorist leaders may still show promising results but only in case that they can convincingly tie their followers to their policy. For counter-terrorism policy, a promising approach would be to confront irrational elements of such a group with strategies of persuasion and appeasement while deterring or bargaining with instrumentally rational elements. Still, it may be difficult to separate instrumentally rational actors from irrational ones within a group, casting doubt on the applicability of such differentiating counter-terrorism strategies.

\subsection{Discussing the identified counter-terrorism strategies}

Concepts of rationality and the previously discussed counter-terrorism measures are clearly illustrated in Table 4. Furthermore, a level of applicability, distinguishing between the individual and collective levels of terrorism, is introduced.

Table 4: Types of Terrorism and Derived Counter-Terrorism Measures

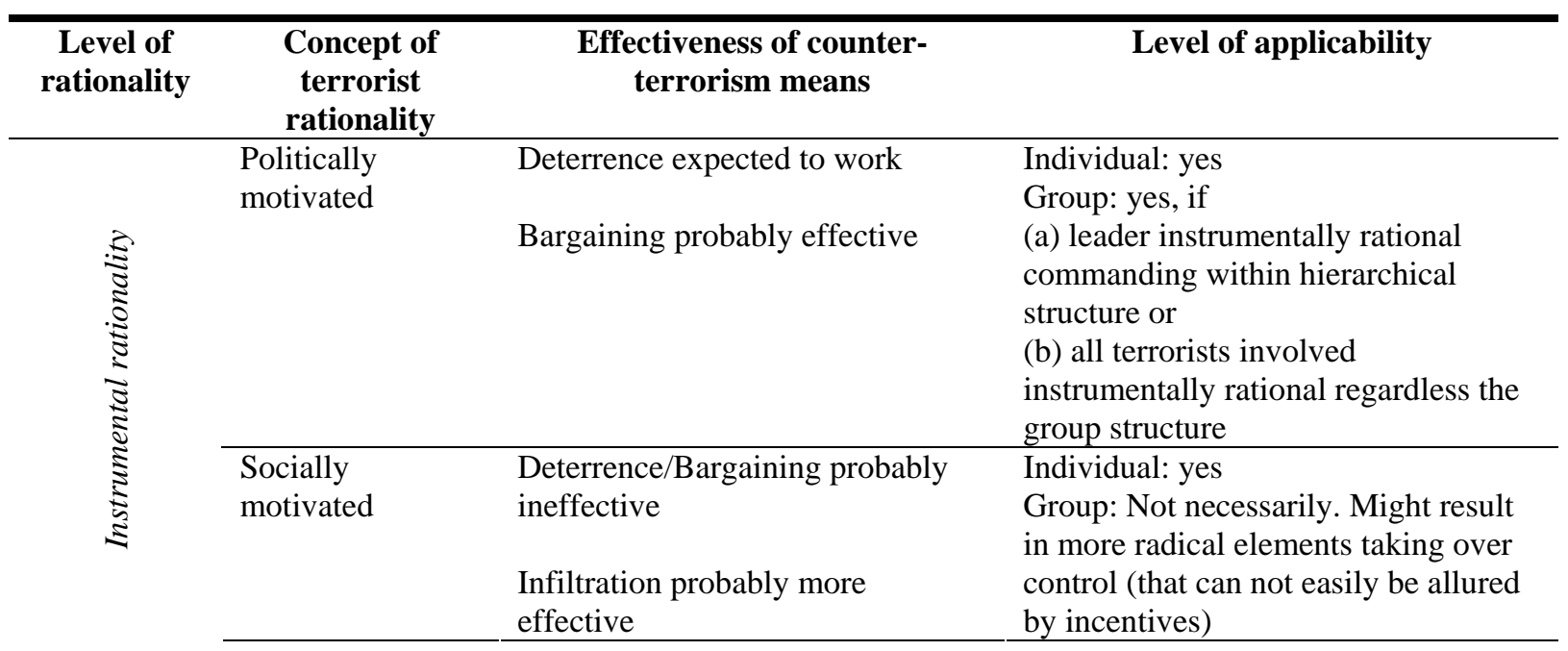




\begin{tabular}{lll}
\hline Motivated by & Deterrence/Bargaining expected to & Individual: yes \\
self-enrichment & work & Group: yes, if
\end{tabular}

Combined approach targeting terrorism and organized crime

(a) leader instrumentally rational commanding within hierarchical structure or promising

(b) all terrorists involved instrumentally rational regardless the group structure

Economically Deterrence expected to work Individual: yes

motivated Group: yes, if

Bargaining probably ineffective

(a) leader instrumentally rational commanding within hierarchical structure or

(b) all terrorists involved instrumentally rational regardless the group structure

\begin{tabular}{|c|c|c|c|}
\hline & & & ? \\
\hline 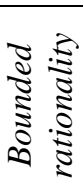 & Unclear & Unclear & Unclear \\
\hline 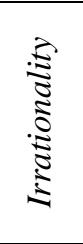 & Unclear & $\begin{array}{l}\text { Deterrence/Bargaining probably } \\
\text { ineffective } \\
\text { Persuasion/Appeasement might } \\
\text { work }\end{array}$ & $\begin{array}{l}\text { Individual: yes } \\
\text { Group: yes, if } \\
\text { (a) leader irrationally commanding } \\
\text { within hierarchical structure or } \\
\text { (b) all terrorists involved irrational } \\
\text { regardless the group structure }\end{array}$ \\
\hline
\end{tabular}

It becomes instantly clear that none of the identified measures is likely to work for all terrorist groups. Bargaining with economically rational terrorists, for instance, is bound to fail while deterrence is not expected to affect the behavior of irrational terrorists. Moreover, seemingly effective strategies will only work on the individual and collective levels of terrorism under certain premises (compare the level of applicability).

As a consequence, not a single counter-terrorism strategy is found to be an optimal mechanism to combat all terrorist actions. Instead, counter-terrorism needs to adapt to the particularities and motivations of a specific terrorist groups. A major problem, however, arises from the failed identification of adequate counter-terrorism measures for bounded rational terrorists. It remains unclear how to confront these groups. 


\section{Conclusion}

This thesis has (1) sought to answer the question if the concept of political rationality is capable of explaining all terrorist behavior or if (2) alternative concepts better explain of terrorism on empirical grounds.

By contrasting the concept of political rationality with alternative concepts varying in degree of rationality or underlying motivation, it was indeed found that terrorists do neither act instrumentally rational in any case, nor do they always strive for political goals. The concept of political rationality could thus not account for all terrorist behavior. But neither was any of the alternative concepts capable of explaining all phenomena of terrorism.

Within the analysis, bounded rationality was identified as the most promising approach to capture and understand terrorism. A good deal of the empirical cases cited is in favor of this concept. On the one side, bounded rationality may account for flawed cost-benefit analyses and imperfect decisions, making these decisions seemingly irrational. On the other side, the concept may also explain, why decisions often seem to be based on thorough calculations, apparently proving instrumentally rational decision-making.

Subsequently, the question (3) needed to be answered, how counter-terrorism strategies should be designed to tackle the various concepts of terrorist rationality and motivations. By focusing only on the concept of political rationality, central aspects of terrorism are ignored and the range of prospective counter-terrorism measures is reduced. For this reason, systematically providing an overview of levels of rationality and differing motivations of terrorism seems more promising to capture all terrorist actions. The conception of terrorism hence influences the pattern of response chosen. This approach allows for a case-by-case analysis of terrorist groups tackling their respective motivations and underlying degree of rationality.

Significant differences were revealed when discussing adequate counter-terrorism measures for the whole spectrum of terrorist motivations and levels of rationality. None of the identified counter-terrorism measures was found to work for all terrorist groups. A general approach to combat all terrorist actions thus seems to be an illusion. Deterrence, for instance, was identified as an adequate policy to tackle politically rational terrorists and economically rational terrorists but is likely to fail when confronting irrational terrorists.

It was further found that levels of rationality may vary within a terrorist group complicating efforts to combat terrorist groups as a whole. As an example, strategies may well work on the individual level and deter individuals from committing terrorist acts but they may still fail on 
the collective level of terrorist groups. With varying degrees of rationality within a terrorist group and a de-centralized organizational structure, it seems highly unrealistic to formulate a consistent and effective counter-terrorism policy which affects the group as a whole.

Disregarding these identified problems, appropriate counter-terrorism measures have been identified both for instrumentally rational and irrational terrorist groups. It needs to be stressed that, in the realm of instrumental rationality, these measures aim at terrorist groups that are purely motivated by a specific goal - be it in economic, social or political terms. The approach of this work thus clearly excludes terrorist groups that strive for more than one goal and cannot give any recommendation on how to tackle these groups.

Moreover, difficulties arose when trying to determine counter-terrorism measures for bounded rational terrorists. Bounded rational terrorists might be approached by perceiving them as instrumentally rational terrorists. Still, as their decisions and behavior may be less than perfect, so will counter-terrorism measures fail to always work. Deterring bounded rational terrorists, for instance, might succeed at times, in case terrorists correctly calculate the impact of counter-terrorism measures at work and refrain from committing violent acts as an instrumentally rational decision. At the same time, terrorists might also miscalculate costs and benefits and still decide to commit violent acts - although this decision might be based on a flawed calculation process. The strength of the concept of bounded rationality in explaining a good deal of terrorism faces severe difficulties when it comes to determining counterterrorism measures to tackle bounded rational terrorists. In other words: We might know how terrorists decide what to do but still we cannot do much about it. This conclusion limits the applicability of an approach trying to cover the whole spectrum of terrorism and to determine adequate counter-terrorism measures.

Despite these limitations, the developed spectrum allows for future empirical-based research. As a possibility, national and supra-national counter-terrorism policies at work can be analyzed to identify the underlying concept of rationality and the perceived motivation of terrorists. Alternative ways to combat specific phenomena of terrorism can then be pointed out. 


\section{Bibliography}

Abrahms, M., 2004. "Are Terrorists Really Rational? The Palestinian Example.” Orbis, 38:3, 533-549.

Abrahms, M., 2006. “Why Terrorism Does Not Work.” International Security, 31:2, 42-78.

Abrahms, M., 2008. "What Terrorists Really Want. Terrorist Motives and Counterterrorism Strategy.” International Security, 32:4, 78-105.

Akerlof, G.A., Shiller, R.J., 2009. Animal Spirits: How Human Psychology Drives the Economy, and Why it Matters for Global Capitalism. Princeton and Oxford: Princeton University Press.

Allingham, M., (ed.), 2006. Rational Choice Theory. Critical Concepts in the Social Sciences. New York: Routledge.

Arce, D.G., Sandler, T., 2005. “Counterterrorism: A Game-Theoretic Analysis.” Journal of Conflict Resolution, 49:2, 183-200.

Crenshaw, M., 1981. “The Causes of Terrorism.” Comparative Politics, 13:4, 379-399.

Bovenkerk, F., Chakra, B.A., 2007. Terrorism and Organised Crime. In: Holmes, L.,2007. Terrorism, Organised Crime and Corruption, 29-41. Cheltenham, UK; Northampton, USA: Edward Elgar.

Boylan, B.M., 2009. “Poverty, Religion, and the Determinants of Domestic Terrorism.” Paper prepared for the 2009 meeting of the International Studies Association in New York. http://www.allacademic.com//meta/p_mla_apa_research_citation/3/1/2/0/5/pa ges312055/p312055-1.php (last accessed on 30 June 2009).

Brauer, J., 2006. "Rational Terrorists: How Terrorist Organizations Employ Economic Principles to Conduct Their Beastly Business." Public Lecture at the University of North Carolina, Asheville, 20 April 2006.

http://www.aug.edu/ sbajmb/paper-Rational_Terrorists.pdf (last accessed on 30 June 2009).

Caplan, B., 2006. "Terrorism: The Relevance of the Rational Choice Model." Public Choice, 128:1, 91-107.

COT - Instituut voor Veiligheids-en Crisismanagement, 2007. "Lone-Wolf Terrorism.” CaseStudy for Work Package 3 on 'Citizens and governance in a knowledge based society' of the EU-based project Transnational Terrorism, Security, and the Rule of Law (TTSRL). Final draft.

http://www.transnationalterrorism.eu/tekst/publications/Lone-Wolf\%20Terrorism.pdf (last accessed on 30 June 2009).

Crenshaw, M., 2000. "The Psychology of Terrorism: An Agenda for the 21st Century.” Political Psychology, 21:2, 405-420. 
De la Corte, L., 2006. “Explaining Terrorism: A Psychosocial Approach.” Perspectives on Terrorism, 1:2, n. pag.

http://www.terrorismanalysts.com/pt/index.php?option=com_rokzine\&view=

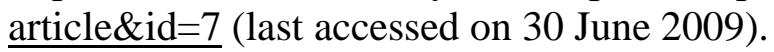

De Mesquita, E.B., 2005. "Conciliation, Counter-Terrorism, and Patterns of Terrorist Violence.” International Organization, 59:1,145-176.

De Mesquita, E.B., Dickson, E.S., 2007. "The Propaganda of the Deed: Terrorism, Counterterrorism, and Mobilization.” American Journal of Political Science, 51:2, 364-381.

Dershowitz, A.M., 2002. Why Terrorism Works: Understanding the Threat, Responding to the Challenge. New Haven, Conn.: Yale University Press.

Dieckmann, A., Voss, T., 2004. Die Theorie rationalen Handelns. Stand und Perspektiven. In: Dieckmann, A., Voss, T., 2004. Rational Choice-Theorie in den Sozialwissenschaften, 13-32. München: Oldenbourg.

Dishman, C., 2005. “The Leaderless Nexus: When Crime and Terror Converge.” Studies in Conflict \& Terrorism, 28:3, 237-252.

Ehrlich, P., Liu, J., 2002. "Some Roots of Terrorism.” Population and Environment, 24:2, 183-192.

Eilstrup-Sangiovanni, M., Jones, C., 2008. “Assessing the Dangers of Illicit Networks. Why al-Qaida May Be Less Threatening Than Many Think.” International Security, 33:2, $7-44$.

Enders, W., Sandler. T., 2002. "What Do We Know about the Substitution Effect in Transnational Terrorism?” Working Paper.

http://www.cba.ua.edu/ wenders/Enders-Sandler.PDF (last accessed on 30 June 2009).

Enders, W., Sandler, T., 2004a: “An Economic Perspective on Transnational Terrorism.” European Journal of Political Economy, 20:2, 301-316.

Enders, W., Sandler, T., 2004b. "Transnational Terrorism: An Economic Analysis." Extended, updated and modified version of "An Economic Perspective on Transnational Terrorism”, which appeared in the European Journal of Political Economy, 20:2, 2004, 301-316.

http://www.utdallas.edu/ tsandler/website/Create_ms_Sandler_aug.pdf (last accessed on 30 June 2009).

Enders, W., Sandler T., 2005. “After 9/11: Is it all different now?” Journal of Conflict Resolution, 49:2, 259-277.

Enders, W., Sandler, T., 2006. The Political Economy of Terrorism. Cambridge: Cambridge University Press. 
Enders, W., Su, X., 2007. "Rational Terrorists and Optimal Network Structure.” Journal of Conflict Resolution, 51:1, 33-57.

Fisher, U.J., 2006. “Deterrence, Terrorism, and American Values.” Paper prepared for the 2006 meeting of the International Studies Association in San Diego. http://www.allacademic.com//meta/p_mla_apa_research_citation/0/9/7/8/8/pa ges97884/p97884-1.php (last accessed on 30 June 2009).

Frey, B.S., Luechinger, S., 2002a: “Terrorism: Deterrence may Backfire.” Paper prepared for the DIW Workshop on "The Economic Consequences of Global Terrorism” in 2002. http://www.diw.de/documents/dokumentenarchiv/17/39104/diw_ws_consequ ences200206_frey_luechinger.pdf (last accessed on 30 June 2009).

Frey, B.S., Luechinger, S., 2002b. "How to Fight Terrorism: Alternatives to Deterrence." Working Paper No. 137. Institute for Empirical Research in Economics, University of Zurich.

Frey, B.S., Luechinger, S., 2007. Decentralization as a Response to Terror. In: Brück, T. (ed.), 2007. The Economic Analysis of Terrorism, 224-230. Abington: Routledge.

Frey, B., 2008. Terrorism from the Rational Choice Point of View. In: Dieckmann, A., Eichner, K., Schmidt, P., Voss, T., (eds.), 2008. Rational Choice: Theoretische Analysen und empirische Resultate, 211-222. Wiesbaden: VS Verlag für Sozialwissenschaften.

Ganor, B., 2008. "Terrorist Organization Typologies and the Probability of a Boomerang Effect.” Studies in Conflict \& Terrorism, 31:4, 269-283.

Gupta, D.K., 2008a. Understanding Terrorism and Political Violence. The Life Cycle of Birth, Growth, Transformation, and Demise. London and New York: Routledge.

Gupta, D.K., 2008b. “Accounting For the Waves of International Terrorism.” Perspectives on Terrorism, II:11, n. pag.

http://www.terrorismanalysts.com/pt/index.php?option=com_rokzine\&view= article\&id=66 (last accessed on 30 June 2009).

Hafez, M., 2006. "Rationality, Culture, and Structure in the Making of Suicide Bombers: A Preliminary Theoretical Synthesis and Illustrative Case Study.” Studies in Conflict \& Terrorism, 29:2, 165-185.

Hindmoor, A., 2006. Rational Choice. New York: Palgrave MacMillan.

Hoffman, B., 1999. Terrorism Trends and Prospects. In: Arquilla, J., Hoffman, B., Lesser, I.O., Ronfeldt, D., Zanini, M., 1999. Countering the New Terrorism, 7-38. Santa Monica, USA: RAND.

Hovi, J., Sprinz, D.F., Underdal, A., 2003. “The Oslo-Potsdam Solution to Measuring Regime Effectiveness: Critique, Response, and the Road Ahead.” Global Environmental Politics, 3:3, 74-96. 
Hutchinson, S., O’Malley, P., 2007. "A Crime-Terror Nexus? Thinking on Some of the Links between Terrorism and Criminality.” Studies in Conflict and Terrorism, 30:12, 10951107.

Jackson, B. A., 2006. "Groups, Networks, or Movements: A Command-and-ControlDriven Approach to Classifying Terrorist Organizations and Its Application to Al Qaeda.” Studies in Conflict \& Terrorism, 29:3, 241-262.

Jackson, B.A., Dixon, L., Greenfield, V.A., 2007. Economically Targeted Terrorism. A Review of the Literature and a Framework for Considering Defensive Approaches. Technical Report. Santa Monica, USA: RAND. http://www.rand.org/pubs/technical_reports/2007/RAND_TR476.pdf (last accessed on 30 June 2009).

Jarvis, L., 2009. “The Spaces and Faces of Critical Terrorism Studies.” Security Dialogue, $40: 1,5-27$.

Jenkins, B.M., 2006. The New Age of Terrorism. In: Kamien, D.G. (ed.), 2006. The McGrawHill Homeland Security Handbook, 117-130. New York: McGraw-Hill.

Josiger, W., 2006. "Getting it right: Understanding Effective Counter-Terrorism Strategies.” Paper prepared for the 2006 meeting of the International Studies Association in San Diego.

http://www.allacademic.com//meta/p_mla_apa_research_citation/0/9/8/4/7/pa ges98470/p98470-1.php (last accessed on 30 June 2009).

Josiger, W., 2009. “Fear Factor. Terrorism's Impact and Effectiveness.” Paper prepared for the 2009 meeting of the International Studies Association in New York. http://www.allacademic.com//meta/p_mla_apa_research_citation/3/1/2/3/7/pa ges312375/p312375-1.php (last accessed on 30 June 2009).

Kahl, T., 2000. Massenmedien und Politik in Russland: Eine Strukturanalyse aus neoinstitutionalistischer Perspektive. Diploma thesis, University of Konstanz, Germany.

Kahneman, D., Tversky, A., 2000. Choices, Values, and Frames. In: Kahneman, D., Tversky, A. (eds.), 2000. Choices, Values, and Frames, 1-16. Cambridge, UK: Cambridge University Press.

Kavanagh, J., 2009: "Selection, Availability, and Opportunity: The Conditional Effect of Poverty on Terrorist Group Participation.” Paper prepared for the 2009 meeting of the International Studies Association in New York. http://www.allacademic.com//meta/p_mla_apa_research_citation/3/1/1/8/6/pa ges311868/p311868-1.php (last accessed on 30 June 2009).

Kirchgässner, G., 2000. Homo Oeconomicus. 2nd edition, Tübingen: Mohr.

Knutsen, T.L., 2006. “Terrorism and the Public Sphere." Paper prepared for the 2006 meeting of the International Studies Association in San Diego. 
http://www.allacademic.com//meta/p_mla_apa_research_citation/0/9/8/1/6/pa ges98161/p98161-1.php (last accessed on 30 June 2009).

Krause, P., 2009. “The Political Effectiveness of Terrorism: Theory and Method.” Paper prepared for the 2009 meeting of the International Studies Association in New York. http://www.allacademic.com//meta/p_mla_apa_research_citation/3/1/2/3/7/pa ges312378/p312378-1.php (last accessed on 30 June 2009).

Krebs, R.R., 2009. “Relationalism, Political Violence, and the Politics of Moderation.” Paper prepared for the 2009 meeting of the International Studies Association in New York. http://www.allacademic.com//meta/p_mla_apa_research_citation/3/1/3/1/2/pa ges313125/p313125-1.php (last accessed on 30 June 2009).

Kydd, A.H., Walter, B.F., 2006. “The Strategies of Terrorism.” International Security, 31:1, 49-80.

Lake, D.A., 2002. "Rational Extremism: Understanding Terrorism in the Twenty-first Century.” International Organisation, 56:1, 15-29.

Libicki, M.C., Chalk, P., Sisson, M., 2007. Exploring Terrorist Targeting Preferences. Monograph. Santa Monica, USA: RAND. http://www.rand.org/pubs/monographs/2007/RAND_MG483.pdf (last accessed on 30 June 2009).

Lipman, B.L., 1991. "How to Decide How to Decide How to...: Modeling Limited Rationality.” Econometrica, 59:4, 1105-1125.

Mandel, R., 1987. Irrationality in International Confrontation. New York: Greenwood Press.

Mayntz, R., 2004. "Organizational Forms of Terrorism. Hierarchy, Network, or a Type sui generis?” MPIfG (Max Planck Institute for the Study of Societies Cologne) Discussion Paper, No. 4.

McCartan, L.M., Masselli, A., Rey, M., Rusnak, D., 2008. “The Logic of Terrorist Target Choice: An Examination of Chechen Rebel Bombings from 19972003.” Studies in Conflict \& Terrorism, 31:1, 60-79.

McCormick, G.H., 2003. “Terrorist Decision Making.” Annual Review of Political Science, Vol. 6, 473-507.

McFadden, D., 1998. “Rationality for economists?” Journal of Risk and Uncertainty, 19:1-3, 73-105.

Meisels, T., 2006. “The Trouble with Terror: The Apologetics of Terrorism - a Refutation.” Terrorism and Political Violence, 18:3, 465-483.

Merari, A., 1993. “Terrorism as a Strategy of Insurgency.” Terrorism and Political Violence, 4:3, 213-251.

Miller, G.D., 2009. "Rationality, Decision-making, and the Levels of Analysis Problem in 
Terrorism Studies.” Paper prepared for the 2009 meeting of the International Studies Association in New York.

http://www.allacademic.com//meta/p_mla_apa_research_citation/3/1/1/8/6/pa

ges311869/p311869-1.php (last accessed on 30 June 2009).

Moghadam, A., 2006: "Suicide Terrorism, Occupation, and the Globalization of Martyrdom:

A Critique of Dying to Win.” Studies in Conflict \& Terrorism, 29:8, 707-729.

Moore, C., 2005. "Combating Asymmetric Threats: Theories and Evidence." Paper prepared for the 2006 meeting of the International Studies Association in San Diego. http://www.allacademic.com//meta/p_mla_apa_research_citation/0/9/7/9/3/pa ges97939/p97939-1.php (last accessed on 30 June 2009).

Neumann, P.R., Smith, L.R., 2005. "Strategic Terrorism: The Framework and its Fallacies.” The Journal of Strategic Studies, 28:4, 571-595.

Oberschall, A., 2004. "Explaining Terrorism: The Contribution of Collective Action Theory.” Sociological Theory, 22:1, 26-37.

Oehme III, C.G., 2008. “Terrorists, Insurgents, and Criminals - Growing Nexus?” Studies in Conflict \& Terrorism, 31:1, 80-93.

Pape, R.A., 2003. “The Strategic Logic of Suicide Terrorism.” American Political Science Review, 97:3, 1-19.

Parsons, S., 2005. Rational Choice and Politics. A Critical Introduction. London, New York: Continuum.

Picco, G., 2005. “Tactical and Strategic Terrorism.” Journal of Aggression, Maltreatment \& Trauma, 9:1, 71-78.

Pittel, K., Rübbelke, D., 2009. "Characteristics of Terrorism.” Economics Working Paper Series, Working Paper 09/103, Swiss Federal Institute of Technology, Zurich.

Post, J., 2007. “Collective Identity: Hatred Bred in the Bone.” Foreign Policy Agenda, 12:5, $12-15$.

Rapoport, A., 1998. Counterproductive Rationality. In: Leinfellner, W., Köhler, E. (eds.), 1998. Game Theory, Experience, Rationality, 35-48. Dordrecht, Netherlands: Kluwer Academic Publishers.

Richardson, L., 2006. What Terrorists Want. Understanding the Terrorist Threat. London: John Murray.

Rosenthal, J.A., 2008. "For-Profit Terrorism: The Rise of Armed Entrepreneurs." Studies in Conflict \& Terrorism, 31:6, 481-498.

Roy, O., 2008. “Al Qaeda in the West as a Youth Movement: The Power of a Narrative.” MICROCON Policy Working Paper 2, Brighton: MICROCON. 
Ruby, C.L., 2002a. "The Definition of Terrorism.” Analyses of Social Issues and Public Policy, 2:1, 9-14.

Ruby, C.L., 2002b. “Are Terrorists Mentally Deranged?” Analyses of Social Issues and Public Policy, 2:1, 15-26.

Sanderson, T. M., 2004. "Transnational Terror and Organized Crime: Blurring the Lines.” SAIS Review, XXIV:1, 49-61.

Sederberg, P.C., 1995. "Conciliation as Counter-Terrorist Strategy." Journal of Peace Research, 32:3, 295-312.

Selten, R., 1999. "What is Bounded Rationality?" Paper prepared for the Dahlem Conference 1999. SFB Discussion Paper B-454. University of Bonn, Germany.

Shapiro, J.N., 2006. “Terrorist Organizations' Vulnerabilities and Inefficiencies: A Rational Choice Perspective.” Paper prepared for the 2006 Meeting of the International Studies Association in San Diego.

http://www.allacademic.com//meta/p_mla_apa_research_citation/1/0/0/6/4/pa ges100640/p100640-1.php (last accessed on 30 June 2009).

Shelley, L.I., Picarelli, J.T., Irby, A., Hart, D.M., Craig-Hart, P.A., Williams, P., Simon, $\quad$ S., Abdullaev, N., Stanislawski, B., Covill, L., 2005. Methods and Motives: Exploring Links between Transnational Organized Crime \& International Terrorism. Research Report.

http://www.ncjrs.gov/pdffiles1/nij/grants/211207.pdf (last accessed on 30 June 2009).

Shughart II, W.F., 2006. “An Analytical History of Terrorism, 1945-2000.” Public Choice, 128:1, 7-39.

Simon, H.A., 1995. "Rationality in Political Behavior.” Political Psychology, 16:1, 45-61.

Sprinzak, E., 2000. “Rational Fanatics.” Foreign Policy, No. 120, 66-73.

Stephan, M.J., Chenoweth, E., 2008. "Why Civil Resistance Works. The Strategic Logic of Nonviolent Conflict.” International Security, 33:1, 7-44.

Stern, J., 2003a. Terror in the Name of God. Why Religious Militants Kill. New York: Harper Collins.

Stern, J., 2003b. “The Protean Enemy." Foreign Affairs, 82:4, 27-41. http://www.cfr.org/publication/6146/protean-enemy.html (last accessed on 30 June 2009).

Victoroff, J., 2005. "The Mind of the Terrorist: A Review and Critique of Psychological Approaches.” Journal of Conflict Resolution, 49:1, 3-42.

Weibull, J.W., 2004. Testing Game Theory. In: Huck, S. (ed.), 2004. Advances in Understanding Strategic Behaviour. Game Theory, Experiments and Bounded Rationality, 85-104. Basingstoke, United Kingdom: Palgrave Macmillan. 
Weitkunat, G., 2008. Terrorismus im Fokus soziologischer Theorieparadigmen. Diploma thesis, University of Hamburg.

Wintrobe, R., 2003. “Can Suicide Bombers be Rational?” Working Paper. http://cas.uchicago.edu/workshops/cpolit/papers/suicide.pdf (last accessed on 30 June 2009).

Zagare, F.C., 1990. “Rationality and Deterrence.” World Politics, 42:2, 238-260.

Zimmerling, R., 1994. 'Rational Choice'-Theorien. Fluch oder Segen für die Politikwissenschaft. In: Druwe, U., Kunz, V., 1994. Rational Choice in der Politikwissenschaft. Grundlagen und Anwendungen, 14-25. Opladen: Leske+Budrich. 